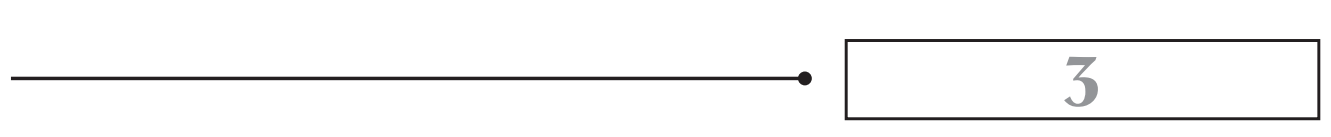

\title{
CONTRATOS DE EXPLORAÇÃO E PRODUÇÃO DE PETRÓLEO
}

\section{$3.1 \quad$ NOTAS INTRODUTÓRIAS}

Suponha que alguém descobrisse que possui um tesouro enterrado no fundo do mar. O seu feliz proprietário, desejoso por se beneficiar dessa riqueza, contrata uma empresa especializada em procurar tesouros e de lá retirá-los. Contudo, como há uma alta probabilidade de fracasso nessa busca, o esperto proprietário decide transferir esse risco para a empresa contratada, remunerando-a não pelos serviços prestados, mas apenas se, e quando, o tesouro for extraído e entregue no local e na forma previamente acertados. Assim, tem-se que o objeto desse contrato será a extração do tesouro das profundezas marítimas, ou seja, ou resultado efetivamente percebido, não os serviços necessários para tanto - que nesse caso constituem-se em mera atividade meio.

Como se trata de um tesouro extremamente valioso, a empresa aceita incorrer no risco, cabendo ao contratante escolher a forma como será feita a remuneração da contratada. Neste sentido, poderá: (a) optar por ficar com todo o seu tesouro, pagando à contratada um valor em dinheiro pela execução do resultado pretendido; (b) em vez de pagar pelo resultado contratado em dinheiro, o faz atribuindo parte do seu tesouro à empresa, ou seja, depois de extraído, o tesouro será repartido entre o contratante e a contratada; ou (c) como a empresa já possui know-how também em negociar o tesouro, o proprietário opta por, além de remunerá-la com uma parte do tesouro, como fez na situação (b), vender diretamente a esta a parte que lhe caberia, recebendo então o valor correspondente à sua parte do tesouro diretamente em dinheiro. 
A história contada ajuda a compreender o objeto das três espécies de contrato de exploração e produção de petróleo utilizadas atualmente na prática internacional: a) contratos de serviço; b) contratos de partilha da produção; e c) contratos de concessão. Costuma-se afirmar, com relação aos contratos de concessão, que seriam eles instrumentos por meio dos quais uma empresa petrolífera adquire o direito de usar um bem público, pagando ao Estado, proprietário do recurso, um preço, chamado de royalty, em contraprestação ao direito de realizar esse "uso qualificado", que lhe permite, além de usá-lo, adquirir a propriedade de parcelas do bem extraído.

Ocorre que o fato de o petróleo ser um bem não renovável impossibilita que se fale em uso deste recurso, ao contrário do que ocorre, por exemplo, com a água. A retirada de alguns litros de água de um rio não é capaz de exauri-lo, por se tratar de um recurso renovável. Ou seja, se o Estado é proprietário de um rio, e por meio de concessão de uso de bem público autoriza uma empresa a retirar " $\mathrm{x}$ " litros de água por dia, durante 15 anos, ao fim desse período continuará sendo proprietário do mesmo rio, que ainda estará presente na natureza.

Por outro lado, o mesmo não se verifica com o petróleo, que é um recurso não renovável. Cada barril de petróleo retirado da jazida resulta na sua gradual exaustão, de modo que, ao final do período de extração, o bem principal (a jazida) terá sido total ou parcialmente extinto. Por esse motivo não é possível haver concessão para exploração do petróleo, no sentido de contrato que autoriza o uso de bem público, pois, sempre que a utilização de um bem por terceiro provocar o seu exaurimento, não terá havido uso, mas sim alienação.

Também não faz sentido o argumento de que se paga pelo direito ao exercício das atividades de exploração e produção, as quais apenas representam meio para a consecução do objetivo final, que é a extração do petróleo. Essa é uma hipótese tão absurda quanto afirmar que uma empresa contratada pela Administração Pública para construir um prédio deve pagar pelo direito de executar os serviços essenciais à conclusão da obra.

Enfim, para a análise das espécies de contratos petrolíferos existentes, parte-se da premissa, a ser mais bem detalhada na seção seguinte, de que o seu objeto é a contratação de um resultado por parte do proprietário do recurso, com o consequente pagamento de um preço à companhia petrolífera pelo trabalho executado, assim como ocorre no exemplo do tesouro.

Pode ocorrer, como mencionado na situação (c), anteriormente explicitada, referente aos contratos de concessão, que o proprietário do recurso opte por vender o petróleo diretamente à empresa que o explorou e produziu. Nesse caso, haverá 
um outro negócio jurídico, de compra e venda, que poderá estar contido no mesmo instrumento contratual por meio do qual foi firmado o negócio jurídico principal, concernente à contratação da extração do petróleo, sem, contudo, com este se confundir. Esta espécie contratual, e as demais apresentadas nas situações (a) e (b), serão analisadas com maior detalhamento nas seções que se seguem.

\subsection{DA IMPOSSIBILIDADE DE SE FALAR EM CONCESSÃO DE USO DE BEM PÚBLICO NO CASO DO PETRÓLEO: CONSIDERAÇÕES ACERCA DO OBJETO DOS CONTRATOS DE EXPLORAÇÃO E PRODUÇÃO DESTE RECURSO}

Ao analisar as espécies de contratos de concessão para uso de bens públicos, Maria Sylvia Zanella Di Pietro expõe de maneira bastante elucidativa, baseando-se nas lições de Raimundo Nonato Fernandes, que esse tipo de concessão pode se apresentar sob duas modalidades: a de exploração ou de simples uso do bem público. $\mathrm{Na}$ primeira, confere-se ao contratado, além do uso, "um poder de gestão dominial, substituindo-se à Administração concedente; como exemplos da primeira, o autor indica as concessões de minas, de águas e de campo de algas" (2011, p. 700, grifos nossos). Na segunda, como o próprio nome sugere, atribui-se apenas a possibilidade de uso do bem público, conforme exemplifica o uso de áreas de dependências de aeroportos, ocupação da via pública, sepulturas e outras. ${ }^{20}$

Após discorrer sobre essas duas espécies de contrato para concessão de uso de bem público - de simples uso e de exploração -, a autora enquadra neste último o aproveitamento de minas e jazidas, ao afirmar que "a jazida pertence ao Estado, que poderá conceder ao particular a sua exploração e aproveitamento” (2011, p. 733).

Tal possibilidade de aproveitamento ou gestão dominial corresponderia a um dos atributos que conformam o uso privativo de bem público por particular, quais sejam: "faculdade de ocupação (como a instalação de bancas na calçada), poderes de transformação (construção de vestiários na praia) ou até poderes de disposição de uma parte da matéria (aproveitamento das águas públicas ou extração de areia)" (DI PIETRO, 2011, p. 692, grifos nossos). Nos contratos de concessão cujo objeto fosse o simples uso de bem público, estariam presentes apenas os dois primeiros

20 Gilberto Bercovici, em posicionamento minoritário, atribui ao contrato de concessão para exploração e produção de petróleo natureza de concessão de simples uso de bem público, explicando que neste caso se confere ao particular a possibilidade de "uso do solo e do espaço aéreo sobre a superfície de terrenos públicos ou particulares” (2011, p. 289). Com isto está o autor a defender que o objeto do contrato seria restrito ao uso de um bem público, argumentando, inclusive, sobre a inconstitucionalidade da apropriação do petróleo extraído pelo concessionário. 
atributos citados - faculdade de ocupação e poder de transformação -, enquanto nos de exploração de bem público, além destes, confere-se também o poder de dispor sobre o bem.

Da mesma forma, Edmir Netto de Araújo, discorrendo sobre o conteúdo do termo "exploração", que caracteriza os contratos para a exploração de bens públicos, ensina que nestes "concede-se também a gestão do domínio do bem concedido (minas, águas, locais paisagísticos/turísticos etc.)” (2010, p. 1.154).

Assim, continua o autor, o uso de bem público “é exercido pela população, por particulares ou pela própria pessoa estatal a que pertence, em benefício do interesse público, que exercitará os poderes de uso, gozo e disponibilidade” (2010, p. 1.147). Referido poder de dispor da coisa, no entanto, consubstancia-se em um "poder de disposição parcial", conforme aduz em seguida, "não podendo importar em alienação da coisa” (2010, p. 1.149, grifos nossos).

Concorda com esse entendimento Alfredo Ruy Barbosa, referindo-se especificamente à concessão minerária, para quem o termo "exploração" revelaria uma espécie de usufruto do bem, na medida em que o contratado teria direito de usar e gerir o recurso, adquirindo-lhe a propriedade após a extração:

De acordo com a legislação brasileira, a concessão mineral atribui um direito exclusivo a um ente privado para explorar e usar uma determinada jazida, desde que este atenda a certos requisitos técnicos, jurídicos e econômicos previstos em lei (...) Assim, a concessão minerária é a transferência de direitos patrimoniais do Estado para um ente privado, a fim de que este possa utilizar e gerir, por sua conta e risco, um determinado recurso natural, com direito de exclusividade e perpetuidade, desde que respeitadas as condições fixadas em lei e a consecução da utilidade pública que constitui a finalidade básica da concessão (2005, p. 14-16, grifos nossos).

Diante do exposto, verifica-se que, de maneira geral, a doutrina que se dedicou ao estudo da natureza dos contratos de exploração e produção de recursos minerais posiciona-se no sentido de que o objeto desses contratos se refere ao uso com poderes de disponibilidade de tais bens públicos.

Com relação ao petróleo, doutrina e jurisprudência também seguem o entendimento de que o objeto dos contratos de exploração e produção desse recurso, seja em que modelo for (contrato de concessão, partilha da produção ou contrato de serviço), refere-se à exploração (no sentido de usufruto) de um bem público pelo particular.

Conforme se passa a expor, discorda-se desse posicionamento por entender ser impossível falar em contrato de uso ou usufruto de um bem público quando o bem em questão for um recurso natural finito. Se a extração e consequente apropriação do recurso natural pelo contratado importar reduzir de maneira permanente a sua 
disponibilidade na natureza, não se está diante de um usufruto (ou uso com poderes de disponibilidade), mas sim de uma alienação progressiva do bem.

Houve um tempo em que seria juridicamente possível defender que um contrato de exploração e produção de petróleo no Brasil teria por objeto o usufruto de um bem público. Isso porque no regime jurídico vigente no país até 1921, não havia distinção entre solo/subsolo e os minérios ou o petróleo nele contidos. Sendo assim, por ser parte integrante do solo/subsolo, o petróleo não era considerado um recurso finito, tendo em vista que poderia ser extraído indefinidamente ao longo do tempo, assim como ocorre com a areia, sem que fosse exaurido permanentemente o bem do qual provinha: a terra.

Contudo, desde a Lei n. 4.265, de 15 de janeiro de 1921, as jazidas de recursos minerais (compreendidas aí também as jazidas de petróleo) passaram a ser tratadas no direito brasileiro como propriedade distinta do solo/subsolo. Com isso, os recursos minerais e petrolíferos presentes no respectivo subsolo deixaram de ser considerados parcelas do solo/subsolo, compondo, isoladamente, uma universalidade de fato, ou um bem coletivo, chamado de jazida, depósito ou campo, conforme o estágio de produção em que se encontre, e, após extraídos, bens singulares (por exemplo, 100 barris de petróleo ou duas toneladas de ferro).

Essa mudança de paradigma a que se faz alusão é, justamente, o que impossibilita falar atualmente em uso - quer do petróleo, quer da jazida. Isso só era possível no regime anterior, quando, conforme leciona Pontes de Miranda na linha do exposto, os minérios presentes no subsolo eram tratados, enquanto aderidos a ele, como parte integrante dele, e, após extraídos, como frutos do solo.

Deve-se ler o art. 61 como se enunciasse: na concepção do direito brasileiro, a terra, o solo, é que é o cerne ou núcleo da propriedade imobiliária; tudo mais é parte integrante do bem, "acedendo" ao solo. (...) Também os minerais contidos no subsolo - ou à superfície (entenda-se) - foram ditos acessório do solo, para se dizer que eram parte integrante do imóvel, cujo cerne é o solo (art. 61): "São acessórios do solo: li. Os minerais contidos no subsolo". Também aqui se hão de entender "minerais e vegetais" (cf. Esboço de Teixeira de Freitas, art. 372, 1a: "Os produtos minerais e vegetais, que o solo espontaneamente fornece, ou com o auxílio de capitais e do trabalho"). (...) Os proprietários do fundo tinham direito exclusivo sobre o subsolo, ou sobre o que se superpunha. Quanto às substâncias a que hoje chamamos minerais ou fósseis, a regra era, a princípio, inexcetuada (Ulpiano, na Lei $7, \$ 14, D ., 24,3$ ); e, separada a greda, a prata, ou o ouro, ou a areia, certamente seria fruto (PONTES DE MIRANDA, 1954, t. II, p. 73, grifos nossos).

Com a individualização da jazida como objeto de propriedade de per si, não cabe mais tomar os minérios extraídos como frutos, uma vez que a sua retirada leva à consequente exaustão da jazida. Ou seja, no cenário anterior os minérios eram 
considerados parte de um todo, que era o solo, de modo que a sua retirada não importava na extinção do bem principal. Havia a possibilidade de se falar, portanto, em exploração desses recursos, no sentido de uso com poderes de disponibilidade, tendo em vista que a retirada do minério ou do petróleo implicava apenas uma disponibilidade parcial do todo, que, repita-se, era o solo/subsolo. $\mathrm{O}$ mesmo não ocorre com relação à jazida. Sendo um todo individualizado, cuja retirada de cada barril leva a sua gradual exaustão, é absolutamente inaplicável falar em uso com poderes de disponibilidade, uma vez que, ao final, haverá o esgotamento do bem principal.

Por esse motivo, se discorda também do posicionamento adotado por Floriano Marques de Azevedo, para quem:

O uso privativo conferido ao concessionário de uma jazida petrolífera dá ao seu titular uma exclusividade no uso (econômico) do bem, sendo certo que a partir do momento em que se utiliza da universalidade (jazida), torna-se proprietário do fruto desta utilização (o hidrocarboneto extraído), fruto este que se aproxima, mas não se confunde com o bem (jazida). (...) De resto, tenhamos em mente que o bem público (jazida) não é alienado ao particular, mas apenas objeto de um direito de exploração que implica na outorga de um uso privativo (2009, p. 331).

Ora, uma jazida nada mais é do que um bem coletivo, formado por milhões de litros de petróleo. Assim como uma biblioteca, exemplo clássico de bem coletivo, só existe enquanto conjunto de livros (sem o que seria apenas uma sala vazia), uma jazida só existe enquanto conjunto de litros de petróleo, sem o que seria apenas um buraco no subsolo.

A retirada de cada livro atinge a própria substância do bem principal (a biblioteca), de modo que ainda que se retire metade do acervo, o bem principal foi permanentemente reduzido. Da mesma forma ocorre com a jazida de petróleo. Não é possível utilizar a jazida, tomando o petróleo como fruto, pois, como afirma Marshall, “o produto da mina é parte da própria mina” (1996, p. 229)!

A jazida constitui-se em um depósito natural de um bem consumível, quer porque armazenado pela natureza, após a sua extração, destina-se à alienação (bem consumível em sentido jurídico), quer pela sua própria natureza, uma vez que o uso do petróleo resulta na destruição da substância (bem naturalmente consumível). ${ }^{21}$

A impossibilidade de se tratar como frutos aquilo que, uma vez extraído, implique o exaurimento do próprio bem, foi também analisada por Pontes de Miranda, que expôs a questão ao definir o conceito de frutos:

21 Segundo o artigo 86 do Código Civil brasileiro, "São consumíveis os bens móveis cujo uso importa destruição imediata da própria substância, sendo também considerados tais os destinados à alienação". 
A expressão "frutos" é empregada no sentido de proveitos econômicos que derivam da coisa conforme o destino que ela tem, ou pode ter parte dela, e sem lhe alterar a essência (CP art. 43, 1-11, quanto a partes integrantes), ou diretamente (frutos naturais), ou por meio de outrem, isto é, como efeito de relação jurídica que tem por fim a obtenção desses proveitos (frutos civis ou jurídicos). (...) O conceito de frutos não apanha os proveitos que se obtêm com prejuízo para a coisa, nem o que é contra o destino econômico da coisa. Os grãos, os frutos, o leite, as crias dos animais, a crina, a lã, o que fica da poda geral das árvores, o esterco, a areia que se explora, o barro, as pedras e outros produtos ou benefícios econômicos semelhantes, são frutos. (...) O que é preciso é que a coisa mesma permaneça: o barro, por mais que dele se tire, não exclui o terreno; nem o giz; nem a pedra (1954, t. II, p. 90).

O interessante é que o autor, mesmo após a alteração no regime de propriedade das jazidas, continuou a se posicionar no mesmo sentido da doutrina citada anteriormente, ou seja, a considerar os minerais extraídos do solo como frutos, com o que, pelas razóes expostas, não se pode concordar.

Ora, como afirmado pelo próprio Pontes de Miranda em diversas passagens: "fruto só é o que da coisa se pode retirar salva substantia sua" (1954, t. II, p. 79) [sic]; “o fruto é o proveito considerado em relação com algum objeto (bem), de que provê-lo, sem no diminuir" (1954, t. II, p. 82); [sic]; "a carne dos bois não é fruto; o boi extingue-se. $\mathrm{O}$ pinto ou o pássaro não é fruto do ovo, - é continuação fática; o ovo, sim, é que é fruto" (1954, t. II, p. 84). E prossegue:

A definição de frutos tem de referir-se a produtos orgânicos, não a todos, e ao que é fruto sem ser produto. Nem se adota, ali, a teoria do produto, nem, aqui, a do proveito. $\mathrm{O}$ que importa é a relação fática de coisa-mãe, ou bem-mãe, a coisa-filha, ou bem-filho, ainda que se insira algum ou muito trabalho humano (1954, t. II, p. 78, grifos nossos).

No caso, a coisa-mãe, ou bem-mãe, não será mais o solo ou o respectivo subsolo, mas a jazida, que se extingue após a extração dos minérios ou do petróleo ali contido, assim como o boi se extingue com a retirada da sua carne.

Destaque-se que a existência de dúvida quanto à caracterização dos minérios como frutos fazia-se presente no Direito Romano, conforme assevera Pontes de Miranda. Ensina que segundo Labeão, as pedras retiradas das pedreiras atingiam a própria substância do fundo, motivo por que não se poderia falar em uso ou usufruto. Javoleno lançou-se contra o argumento de Labeão, exemplificando com as minas de mármore, que renasciam:

Quanto à cal, à greda, à areia, ao barro e semelhantes, já Labeão admitia que fossem usados para o necessário e Ulpiano pô-los, sem qualquer distinção, na classe dos frutos (Lei 12, pr., D., de usufructu, 7, 1; L. 7, \$13, D., 24, 3); mas ele mesmo teve de distinguir se há ofensa à parte necessária do campo (si non agri partem necessariam 
huic rei occupaturus est). Importa dizer-se se a fazenda é de café, ou de cana-de-açúcar, ou de cacau, e o tirar o barro diminui-lhe o valor como fazenda, - o barro desde onde começa a diminuir-lho não é fruto. $O$ que é renascente, como a água mineral, sempre é fruto. Também o gelo natural. Não, para o direito romano, a água profluente (aqua profluens) (PONTES DE MIRANDA, 1954, t. II, p. 83).

Diante de todo o exposto, tem-se que, se não se pode falar em uso, quer do petróleo, quer da jazida, sendo, portanto, impossível atribuir aos contratos de exploração e produção de petróleo natureza de contrato de concessão de uso de bem público, cabe indagar: o que se teria então? A resposta foi dada por Maria Helena Diniz, que embora sem discorrer com profundidade sobre o assunto, ao analisar a natureza jurídica de tais contratos, caracterizou-lhes como contrato de empreitada. Segundo a autora, "seria um contrato de empreitada com fornecimento de material por parte da sociedade empreiteira, que se obrigará a realizar obra determinada ou a produzir certo resultado em favor do empreitante; logo, o serviço prestado será o meio e não o fim, pois o importante é a promessa do resultado, de tal sorte que a despesa com a exploração não será ressarcida se o resultado for negativo" (2006, p. 569-570).

De forma similar, posicionou-se também Ana Raquel Gonçalvez Moniz, que ao diferenciar concessões para a exploração do domínio público, concessões de serviços públicos e concessões de obra pública, em que esta venha a constituir um bem dominial, enquadra neste último tipo o "domínio público mineiro e o domínio público infraestrutural” (2006, p. 401).

Com algumas ressalvas, concorda-se com o posicionamento das autoras, pois, tanto no contrato de concessão, como no de partilha da produção, o Estado contrata uma empresa visando um resultado bem definido: a extração do petróleo, nas formas e condições estabelecidas na lei e no contrato. Todos os serviços executados pela empresa, assim como os bens por ela utilizados durante o processo produtivo, destinam-se unicamente à consecução do resultado pretendido pelo Estado por ocasião da contratação.

Essa conclusão fica mais nítida quando se analisa a definição de obra dada por Pontes de Miranda, a qual corresponderia ao objeto do contrato de empreitada:

A obra pode consistir em criar o bem que se quer, ou em destruí-lo, ou em modificá-lo. Há, por exemplo, respectivamente, a empreitada para edificar a casa, ou para tirar o cômoro ou a mata e jogar no mar, ou no rio, ou queimar, como há a empreitada para fazer mais um andar no prédio, ou apenas para pintá-lo. A prestação de serviços não é devida como serviços, mas pelo resultado. Os serviços, na empreitada, apenas são meios para se obter aquilo que se prometeu. (...) Se o contratante se vinculou a preparar partes em determinada área, ou plantar cafezal, ou derrubar matas, ou 
remover terras, ou colher os frutos da safra, uma vez que tem de dar a obra pronta, mediante remuneração, o contrato é de empreitada (1972, t. XLIV, p. 375, grifos nossos).

Os exemplos postos pelo autor fazem com que se enxergue com mais clareza a forma como se aproximam o objeto dos contratos de exploração e produção de petróleo e o contrato de empreitada. Contrata-se a retirada do petróleo, assim como a do cômoro ou da mata.

Nos contratos de partilha da produção e de serviço, certamente a visualização do resultado pretendido pelo proprietário dos recursos (Estado) é mais fácil de ser percebida. A empresa contratada deverá extrair o petróleo, que continua pertencendo ao Estado após extraído, remunerando-se com uma parte desse óleo ou em pecúnia. Desse modo, o Estado recebe o resultado contratado, isto é, o petróleo, estando livre para aliená-lo a outras empresas, por meio de outro instrumento contratual, cujo objeto será a compra e venda do petróleo, que em nada tem a ver com aquele firmado com a empresa que extraiu o recurso. A empresa contratada para a extração do petróleo, por sua vez, ao ser remunerada por meio do recebimento de uma parte do petróleo extraído (no contrato de partilha), também poderá comercializá-lo da forma que lhe aprouver, respeitando os limites impostos pela Lei, notadamente no que tange à manutenção de estoques para o consumo local.

No contrato de concessão, embora o Estado também pretenda obter o mesmo resultado, este é mais difícil de ser visualizado na prática; isto porque, neste, a despeito de a finalidade pretendida ainda ser a extração do petróleo, opta o ente público por vendê-lo diretamente à empresa que extraiu o recurso, recebendo sua participação no resultado, portanto, convertida em pecúnia, na forma de royalties, conforme será analisado detalhadamente nos capítulos seguintes.

Há no contrato de concessão, portanto, um acordo concomitante de compra e venda, de modo que a parcela em petróleo que caberia ao Estado é alienada diretamente à empresa concessionária, que paga, em contraprestação, um valor em dinheiro chamado de royalty, correspondente ao preço pelo bem público adquirido.

Por fim - e esta é a ressalva que se faz ao posicionamento de Diniz e Moniz quanto à caracterização dos Contratos de E\&P como empreitada ou obra pública -, é importante destacar que não se está a afirmar que os contratos em análise seriam contratos típicos de empreitada, como previsto no Código Civil, ou mesmo de obra pública, regulado pela Lei n. 8.666/93. Estes contêm aspectos próprios que não se aplicam aos contratos petrolíferos, os quais, por sua vez, possuem características tão peculiares que os tornam contratos sui generis em relação a qualquer outro ajuste firmado pela Administração. 
Tampouco se discute se constituem contratos de direito público ou privado, assunto que comporta relevante discordância entre os administrativistas. Apenas se ressalta que o objeto desses contratos se assemelha aos contratos de empreitada ou de obra pública, conforme ensinado pelas autoras, por entender que assim como nestes, contrata-se de empresa privada ou estatal um resultado, que, repita-se, consiste na extração do petróleo, e sua entrega na forma e condições previstas no contrato e na lei.

A compreensão do objeto desses contratos mostra-se fundamental para que seja possível entender a natureza das prestações devidas por cada uma das partes, e, assim, compreender a natureza dos royalties, ponto central deste trabalho.

\subsection{DA IMPOSSIBILIDADE DE SE FALAR EM CONCESSÃO PARA O EXERCÍCIO DE UMA ATIVIDADE ECONÔMICA}

Há ainda uma parte da doutrina segundo a qual o objeto dos contratos de exploração e produção de petróleo seria: a atribuição de um direito de exercer uma atividade econômica monopolizada pelo Estado, de modo que o pagamento das participações governamentais seria devido em contraprestação ao exercício desse direito.

Esse é o entendimento de Fabio Francario, administrativista italiano, o qual defende, com base nas lições de Guarino e Giannini, que o pressuposto da concessão não pode consistir no gozo de um bem, mas sim "na transferência do exercício de uma atividade, quais sejam, aquelas de pesquisa e produção das substâncias minerais, atividades reservadas pelo legislador ao Estado" (2003, p. 1.807, tradução nossa). A partir dessa conclusão, postula que a concessão mineral seja explicada "em termos de empresa, que são os direitos do empresário sobre bens de terceiros utilizados pela empresa, e não em termos de (...) direitos reais” (2003, p. 1.807, tradução nossa, grifos nossos).

Prossegue em sua explicação, tomando por referência os estudos de Cassese, para quem "é bem claro que não só para as minas, mas também para as pedreiras, o regime não pode ser explicado se não se tem presente que no centro do comando normativo não está a propriedade, mas a empresa” (2003, p. 1.808, tradução nossa, grifos nossos).

Também Alexandre Santos de Aragão assinala que os contratos de concessão para exploração e produção de petróleo constituem-se em concessóes econômicas ou industriais, cujo objeto seria o direito de exercício de uma atividade que a lei reservou para a Administração, de modo que o que estaria em causa - enfatiza - "não é a utilização do bem, mas a actividade de o explorar ou gerir" (2006, p. 18, grifos nossos). O contratado estaria tutelado por meios que permitam materialmente o contato com a coisa, mas "não é a coisa, seja ela chamada de bloco, 
área, jazida ou elemento, o que se está a conceder. Está-se, no plano obrigacional, outorgando direito de exercer atividade econômica" (2006, p. 16).

Ora, toda realização de atividade econômica representa um ônus, que é recompensado quando o bem ou serviço produzido por meio dessa atividade é negociado e o preço pago por ele é capaz de cobrir os investimentos do empreendedor, além de lhe gerar uma margem de lucro adequada.

No caso de uma empresa que preste serviço de telefonia, a sua remuneração é devida pelo usuário do serviço, assim como ocorre com uma distribuidora de energia elétrica, que recebe uma tarifa paga pelo usuário em decorrência do bem fornecido. No caso das companhias petrolíferas, quem paga pelo trabalho de exploração e produção executado?

O que gera um benefício econômico para a companhia petrolífera é a remuneração pelo trabalho prestado, paga pelo proprietário do recurso natural, que pode ser em dinheiro (no caso dos contract services) ou em óleo (no caso dos contratos de partilha da produção e de concessão).

As consideraçõos feitas pela doutrina italiana, bem como na doutrina brasileira por Aragão, pecam por considerar as atividades de exploração e produção como sendo a finalidade de um contrato petrolífero, quando, na verdade, são apenas atividades-meio para a execução do contrato, que visa obter um resultado: a extração do petróleo. Nenhuma empresa petrolífera está interessada simplesmente em desenvolver as atividades de exploração e produção. Se o foco da companhia fosse apenas o exercício dessas atividades, após a extração o recurso seria entregue ao seu proprietário e estaria concluído o contrato. Ou seja, a empresa teria realizado uma infinidade de gastos tão só porque gostaria de fazer um favor ao proprietário do recurso, sem nada receber em troca, pois ela teria alcançado seu grande objetivo, que é gozar do direito de explorar e produzir o petróleo. Certamente não é isso o que ocorre. A empresa deseja contratar com o proprietário do recurso, pois visa ser remunerada pelo trabalho prestado, em dinheiro ou em petróleo.

Aragão afirma que o que estaria em causa seria o direito de exercer uma atividade econômica, de explorar ou gerir o recurso. Como visto, não é possível se falar em exploração do petróleo, no sentido de usufruto, porquanto, após a sua extração, ele é alienado ao particular, promovendo o gradual exaurimento da jazida. Também não se verifica, na prática, a possibilidade de uma empresa gerir o petróleo da União. Não se trata de um bem pertencente ao ente público, como um prédio, que estará em poder de terceiro, para que este possa geri-lo e, a qualquer tempo, ser reavido pelo seu titular. O que ocorre após a extração do petróleo, repita-se, é uma transferência de propriedade, do ente público para o particular. A partir de então, 
o particular irá gerir seus próprios barris de petróleo, recebidos em contraprestação ao trabalho encomendado pelo proprietário dos recursos (forma de remuneração típica dos contratos de concessão e de partilha da produção).

Qualquer pagamento, pelo mero direito de contratar com a Administração Pública, seria um encargo contratual relacionado ao procedimento de licitação para a escolha do contratante, a exemplo do que ocorre com o bônus de assinatura, presente nos contratos petrolíferos, o qual, entretanto, não tem qualquer relação direta com o objeto do contrato, como ocorre no caso dos royalties.

\subsection{DOS MODELOS CONTRATUAIS PARA EXPLORAÇÃO E PRODUÇÃO DE PETRÓLEO UTILIZADOS NA PRÁTICA INTERNACIONAL}

Observa-se na prática internacional que, de maneira geral, os Estados têm optado por viabilizar a extração do petróleo mediante a contratação de empresas públicas ou privadas, dotadas de capacidade operacional para explorar e produzir esse recurso. Os termos em que serão desenvolvidas essas atividades, bem como os direitos e deveres a cargo de cada uma das partes (Estado - normalmente representado por agência estatal ou empresa governamental - e companhia petrolífera) são positivados por meio de instrumentos contratuais, denominados, segundo Marilda Rosado, de contratos petrolíferos, ou contratos de exploração e produção petrolífera. Nestes, "são previstos os direitos e as obrigaçóes decorrentes dos direitos conferidos pelo Estado em relação à utilização e destinação das reservas petrolíferas" (2003, p. 161).

Ao longo dos anos, três modelos contratuais se consolidaram como sendo de utilização corrente para fins de contratação de empresa para o exercício das atividades em comento: 1) os contratos de concessão, 2) de partilha da produção e 3) de serviço, com ou sem risco. Apesar de cada um deles guardar características peculiares, conforme será evidenciado a seguir, divergem entre si basicamente pelos seguintes aspectos: a forma pela qual o Estado opta por perceber o resultado do trabalho contratado e o meio pelo qual o contratado será remunerado.

Entre os três modelos mencionados, o primeiro a ser utilizado na indústria do petróleo foi o contrato de concessão. Anthony Jennings relata que, historicamente, sobretudo no início do século passado, as grandes companhias de petróleo detinham concessôes em várias partes do mundo, "na maior parte das vezes em locais sobre os quais os governos dos Estados Unidos e do Reino Unido exerciam forte influência, particularmente no Oriente Médio" (2002, p. 4, tradução nossa). Essas concessões, normalmente, atribuíam direitos exclusivos de explotar óleo e gás, com pouco controle estatal, durante longos períodos, e frequentemente sobre vastas áreas. O governo hospedeiro reservava para si pouco ou nenhum direito de participar do processo de 
explotação e demais operações sobre qualquer campo em desenvolvimento. Embora considerado vantajoso naquele período, "em razão da expertise detida pelas companhias de petróleo, pouco a pouco esses contratos passaram a ser vistos como excessivamente generosos para as companhias privadas" (JENNINGS, 2002, p. 4, tradução nossa), pelo que, a partir dos anos 90, foram reformulados, passando-se a adotar o que se chamou de contrato de concessão do pós-guerra. Estes, conforme ensina Marilda Rosado, contêm os seguintes atributos:

a empresa internacional de petróleo (IOC) tem o direito exclusivo de explorar e explotar petróleo, por sua conta e risco; ela é proprietária do óleo produzido, ficando livre para dele dispor, mas assegurando parcela para abastecimento do mercado doméstico do país hospedeiro; durante a fase de exploração e explotação paga taxa de arrendamento da área; a IOC paga royalties em óleo, em espécie, ou uma combinação dos dois e imposto de renda; ela é proprietária dos equipamentos e ativos; não há participação ou ingerência do país hospedeiro, que também não se beneficia de treinamento ou transferência de tecnologia (2003, p. 162).

Ao discorrer também sobre as características que informam os contratos de concessão, Terence Daintith, após realizar uma análise comparada do regime adotado em diversos países, expõe que "em cada um deles, as licenças, ou qualquer outro nome que seja dado - concessão é a forma mais comum de se chamar esses contratos - possuem de maneira geral o mesmo conteúdo e efeitos” (1981, p. 9, tradução nossa). Assim como assinalado por Rosado, o autor explica que por um dado período e sobre uma determinada área, são atribuídos ao contratado direitos exclusivos de exploração e produção, transferindo-se a ele a propriedade de todo o petróleo extraído. Em contrapartida "o contratado paga ao Estado uma certa quantidade de tributos, bem como royalties sobre a produção, aceitando um amplo conjunto de obrigações, além de se sujeitar à supervisão do Estado sobre suas operações" (1981, p. 9, tradução nossa).

Contudo, conforme destaca Anthony Jennings, nem sempre uma mesma companhia é contratada para a realização de ambas as atividades. No Reino Unido, por exemplo, existem dois tipos de concessão, uma para as atividades de exploração, e outra para as de produção de petróleo.

Offshore licences in the United Kingdom are limited to two types, the exploration licence and the production licence. The term production licence is a little misleADIng, since such a licence is actually needed for many exploration activities. Without a production licence, a company can only explore by means of conducting geological surveys; thus any wells for discovery or delineation purposes can only be drilled under production licences. The production licence is a much more comprehensive document which not only permits these exploration activities but also the getting and taking away of petroleum, the ultimate goal of the operator, though it does not authorise the laying of pipelines (JENNINGS, 2002, p. 3). 
Vale ressalvar que essa forma de contratação, apenas para o desempenho de atividades de exploração de petróleo, diverge do que se entende na doutrina por contrato de concessão típico, uma vez que, para a caracterização deste, é essencial que, no mínimo, duas características estejam presentes: 1) a empresa contratada torna-se proprietária do petróleo no exato momento em que este passa pela boca do poço; e 2) o Estado opta por receber a parte que lhe cabe da produção convertida em pecúnia, por meio do que se convencionou chamar de royalties.

Além dessas, Taverne cita outras cláusulas tidas como padrão nesse modelo contratual, quais sejam: a duração da concessão, que normalmente pode ser prorrogada por uma ou mais vezes; a obrigatoriedade de cumprir um programa mínimo de exploração; a apresentação de um plano de desenvolvimento e cronograma de produção; o pagamento de participações governamentais, sob a forma de royalties, bônus e outras contribuiçỗes específicas; a responsabilidade por danos e pela forma de resolução de conflitos (TAVERNE, 1999).

Com relação aos dois outros modelos mencionados - contratos de partilha da produção, conhecidos por production sharing agreements (PSA) ou production sharing contracts (PSC), e os contratos de serviço (service contracts) -, Bernard Taverne (1999) tratou-os como espécies de contratos de trabalho (contracts of work), nos quais há uma relação contratual entre um ente estatal ${ }^{22}$ de um lado e uma empresa de petróleo pública ou privada do outro, contratada, assim como nos contratos de concessão, para a condução das atividades de exploração e produção de petróleo, dentro de uma área específica, em consonância com as regras e condições estabelecidas no contrato. Contudo, apesar dessas semelhanças, divergem dos contratos de concessão por um ponto fundamental: tanto no contrato de partilha da produção, quanto no de serviço, o petróleo extraído continua sendo propriedade do Estado. Naquele, o contratado será remunerado por meio do recebimento de uma parcela do óleo extraído (in natura), enquanto neste terá direito apenas a ser remunerado pelo trabalho prestado, em dinheiro.

Sobre o momento em que a propriedade do óleo é transferida para os contratados, ensina Johnston que:

From a legal point of view, the timing of the transfer of title and ownership is important. If disputes arise, the closer the contractor is to actual physical ownership, the stronger the legal position. As far as ownership is concerned, under a PSC the

22 "The state party may be the State itself, or an authority representing the State such as a government ministry or a petroleum directorate established within a ministry. The state party may also be a state oil enterprise i.e. a state owned and controlled oil company, usually referred to as the national oil company specially established for the purpose of managing and developing the national petroleum resources" (TAVERNE, 1999, p. 153-154). 
contractor does ultimately receive a share of production and hence takes title to the crude. The transfer of title is effectively shifted from the wellhead under a concessionary system to the point of export under a PSC. With a service or risk service agreements, the issue of ownership is removed altogether (JOHNSTON, 1994, p. 23).

Analisa-se a seguir, de forma mais detida, cada um deles, a começar pelo contrato de partilha da produção.

A doutrina é unânime em apontar a Indonésia como pioneira na adoção do production sharing agreements, tendo o seu primeiro contrato sido firmado em agosto de 1966, entre a IIAPCO e a Permina, a Companhia Nacional de Petróleo da Indonésia, atual Pertamina.

Apesar de terem sido criados no início dos anos de 1960, quando os países produtores de petróleo passaram a reivindicar para si maior controle sobre as operações desenvolvidas em seu território, apenas a partir dos anos de 1970 os PSAs ganharam notoriedade, passando a ser adotados no Egito, Síria, Indonésia, Peru e Papua Nova Guiné. Com a sua posterior utilização pela Rússia, ${ }^{23}$ tornou-se o "contrato da moda”, sendo atualmente aquele que mais tem crescido em termos de adesão, seja pelos países que estão a reformular as regras anteriormente adotadas, como no caso do Brasil, seja por aqueles que apenas recentemente descobriram depósitos de petróleo em seu território e se acham a implantar normas para regular o setor.

Segundo Marilda Rosado, contratos de partilha de produção são aqueles em que: a estatal do país hospedeiro tem participação na administração e a IOC assume o risco da parte técnica e financeira da operação em uma determinada área sob contrato; a produção pertence ao país hospedeiro; após recuperação dos custos, a produção é rateada entre a estatal e a IOC, de acordo com percentual predeterminado; a renda da IOC é sujeita a tributação; os equipamentos e instalações são propriedade do país hospedeiro (2003, p. 163-164).

Até hoje, conforme ensina Johnston, em todos os contratos de partilha da produção em vigência no mundo, embora se verifiquem inovações em um ou outro aspecto, adota-se ainda, basicamente, o mesmo padrão contratual concebido

23 "Russia has become a fashionable exploration province over the last decade, and PSAs have developed very rapidly there. They are an accepted part of the system there by majors and independents alike, whose shared aim is to limit their exposure to excessive taxes as far as possible. This risk tends, as we will see, to be greater under a concession regime. However, it is a fact of life recognised by all who have dealings in Russia that there will be frequent use of the term bureaucracy in connection with the Russian administration of matters legal. PSA in Russia have thus become needlessly complex, combining elements of a concessionary system with what should be a simple contractual one. There is no alternative for the oil company but to swallow and pay homage to the insatiable Russian appetite for regulation and control" (JENNINGS, 2002, p. 6). 
originariamente pela Indonésia, cujas cláusulas mais significativas, reproduzidas em outros regimes, eram as seguintes:

- O título de propriedade dos hidrocarbonetos permanece com o Estado.

- A Permina mantém o controle administrativo, e o contratado é responsável juntamente com a Permina pela execução das operações de petróleo em consonância com os termos do contrato.

- Requer-se do contratado a submissão de um programa anual de trabalho e do seu balanço para aprovação da Permina.

- O contrato baseia-se na partilha da produção e não em uma partilha de lucros.

- O contratado provê todos os recursos financeiros e tecnologia requerida para as operaçōes e suporta os riscos.

- Durante a vigência do contrato, após autorização para utilização de no máximo $40 \%$ da produção anual de petróleo para a cobertura dos custos, a produção remanescente é partilhada na base de 65\%/35\% em favor da Permina. As participaçôes governamentais a cargo do contratado eram pagas em óleo, entregue a Permina.

- Todos os equipamentos comprados e importados na Indonésia pelo contratado tornam-se propriedade da Permina. Equipamentos pertencentes a companhias prestadoras de serviço e aqueles alugados, estão fora dessa regra (1994, p. 40).

Verifica-se que neste modelo contratual o Estado opta por receber o resultado do trabalho contratado in natura, devendo ele mesmo comercializar a parcela da produção que lhe coube, por meio de contrato de compra e venda de petróleo, firmado normalmente com refinarias ou com grandes consumidores de energia. Somente a partir daí é que se dá efetivamente o ingresso de receita pública nos cofres públicos, passível de ser aplicada nas finalidades elegidas pelo Estado.

Vistos tais aspectos, que serão mais minudentemente abordados quando forem analisadas as regras aplicáveis ao contrato de partilha da produção, adotado recentemente no Brasil, passa-se a discorrer sobre a terceira forma conhecida para a contratação de empresas pelo Estado quanto ao exercício das atividades de E\&P: os contratos de serviço. Como exposto anteriormente, nos contract services, o petróleo explotado continua sendo propriedade do Estado, que remunera o contratado integralmente em dinheiro, conforme ensina Jennings:

these, like PSAs, grant only contractual rights, not proprietary rights, but they confer even less control on the oil company as they differ from PSAs in one fundamental way: at no point does the company gain title to production, except perhaps subsequently under a sale and purchase agreement (2002, p. 12).

Tal qual elucidado pelo autor, ao contratado não é devido direito algum de se apropriar dos recursos produzidos, restando-lhe firmar, posteriormente com o Estado, caso deseje, contrato de compra e venda de petróleo. Contudo, em alguns 
países, assegura-se ao contratado prioridade na compra do petróleo, por vezes com um desconto em relação ao preço praticado no mercado (JENNINGS, 2002).

Com relação à diferença entre contratos de serviço com ou sem risco, Johnston esclarece:

The difference between risk service and pure service contracts depends on whether the fee is based on profits or not. Pure service contracts are quite rare. In pure (nonrisk) service contracts the contractor carries out exploration and/or development work on behalf of the host country for a fee. All risk is borne by the state. This arrangement is characteristic of the Middle East where the state often has substantial capital but seeks outside expertise and/or technology (JOHNSTON, 1994, p. 24).

Como bem dito pelo autor, é rara a utilização de contratos de serviço de risco por parte dos Estados, uma vez que se obrigam a pagar à empresa pelos serviços contratados, ainda que não haja tido sucesso na busca por campos viáveis de ser explotados, assumindo, portanto, todo o risco da atividade.

Por fim, é importante que se entenda que os modelos apresentados são apenas fórmulas padrões utilizadas pelos Estados, podendo variar significativamente de um país para outro. Ademais, novos arranjos têm surgido; exemplo disso é o contrato de cessão onerosa no Brasil, a seguir analisado, ou os contract-based ROR system, adotados em Papua Nova Guiné e na Guiné Equatorial, conforme relata Johnston:

Rate of return (ROR) features are also found in both systems. ROR is more a descriptive term to identify further the nature of a particular system. For example, the Papua New Guinea (PNG) fiscal system is a concessionary-based ROR system. Equatorial Guinea, on the other hand, uses a PSC-based ROR contract. The ROR concept can get slightly exotic. And it appears to be a new direction for the industry (JOHNSTON, 1994, p. 27).

\subsection{DOS MODELOS CONTRATUAIS CONSTITUCIONALMENTE AUTORIZADOS NO BRASIL PARA AS ATIVIDADES DE E\&P}

Entre os diversos tipos de contratos conhecidos na experiência internacional, destinados a regular as relações jurídicas concernentes ao Estado - proprietário dos recursos naturais (no caso, do petróleo) - e as empresas que atuam no setor de exploração e produção desse recurso, cabe ao ente público adotar aquele que julgue mais conveniente para a consecução dos seus interesses, podendo utilizar como modelo um dos citados na seção anterior, ou ainda, desenvolver um sistema misto, combinando características de uns e de outros.

Há países em que o Poder Executivo firma diretamente o contrato com a companhia petrolífera, não havendo qualquer norma regulando o assunto; somente, em alguns casos, disposições constitucionais genéricas enfatizando a propriedade 
pública sobre os recursos naturais. ${ }^{24}$ Em outros, como é o caso do Brasil, os contratos firmados entre o poder público e as empresas petrolíferas estão vinculados a leis que dispõem, muitas vezes de maneira bastante detalhada, sobre cláusulas essenciais e parâmetros a serem observados no instrumento contratual, determinando, até mesmo, qual o tipo de contrato a ser adotado.

Discutem-se, na doutrina brasileira, os limites constitucionais a que está sujeito o legislador ordinário ao decidir por adotar este ou aquele modelo. Estaria ele livre para escolher qualquer um daqueles utilizados na experiência internacional? A doutrina e a jurisprudência não são pacíficas ao responder a esse questionamento.

A existência de dúvidas quanto ao tema levou à proposição da Ação Direta de Inconstitucionalidade 3.273-9/DF, comentada anteriormente, quando se analisou o regime jurídico do petróleo como bem público. $\mathrm{Na}$ ação interposta perante o Supremo Tribunal Federal, discutiu-se a constitucionalidade do artigo 26 da Lei n. 9.478/97, o qual atribui à empresa contratada para o exercício das atividades de exploração e produção de petróleo, pelo sistema de concessão, a propriedade do produto da lavra, isto é, do petróleo extraído, mediante o pagamento das participaçôes governamentais devidas.

Argumentou-se que referido dispositivo legal feria o artigo 177 da Constituição Federal, que conferia à União o monopólio do exercício das atividades de exploração e produção de petróleo no Brasil, de modo que, mesmo após a Emenda Constitucional n. 9/95, em face da manutenção da expressão monopólio no texto constitucional, o ente público apenas poderia contratar empresas públicas ou privadas para a execução de tais atividades, sem, contudo, atribuir-lhes o produto da lavra.

Antes, porém, de ingressar na análise dos argumentos constantes do julgamento, tanto por aqueles que defendiam a inconstitucionalidade do dispositivo, como por

24 Conforme expõe Terence Daintith: "Each system expresses the licence relationship in some combination of a document personal to the licensee - that is, the licence itself - and a related set of legislative or regulatory prescriptions. There is, however, no uniformity as to the way in which this combination is made up. In the United Kingdom, all the terms are in the licence which is contractual in form and there are no regulated regulations, but model licence terms are laid down by regulation and are replicated en bloc in the licence. In Canada, by contrast, terms are divided between a contractual lease, on the one hand, and statutory regulations, which are expressed to govern the lease, on the other. In Norway and Greenland there is a similar division, but it is not clear that the licence or concession itself is contractual in form. In Denmark and Australia there are no regulations, only legislation and licences (in the case of Denmark, a single licence) granted under the authority of that legislation. While in Australia the essential terms are all contained in the legislation itself, in Denmark they are contained in the licence, though this repeats certain provisions contained in the legislation and which that legislation requires to be included in the licence. In neither case, however, is the licence expressed to be a contract" (1981, p. 9-10). 
aqueles que sustentavam a sua conformidade com o texto constitucional, é conveniente que se faça uma breve exposição acerca dos artigos constitucionais que foram objeto de debate, de modo a facilitar a compreensão da questão.

No Brasil, o exercício das atividades de exploração e produção de recursos minerais (pois o legislador constituinte considerou o petróleo como uma espécie de recurso mineral) encontra-se regulado desde a Constituição Federal, perpassando por diversas leis ordinárias, até uma série de atos infralegais - decretos, portarias, regulamentos etc. Na Constituição de 1988, o tema foi tratado nos artigos 176 e 177, versando o primeiro sobre o regime geral aplicável a todos os minérios, e o seguinte contendo regras que concernem exclusivamente ao petróleo.

Neste sentido, dispôs-se no artigo 176 que a realização das atividades de pesquisa e lavra de minérios em geral somente poderá se dar mediante autorização ou concessão da União, ente público que detém a propriedade desses recursos enquanto se encontrem aderidos ao solo, na forma de depósito, jazida ou campo, assegurando-se ao concessionário, contudo, a propriedade do produto da lavra. Segundo o texto constitucional, determina-se ainda que as atividades em questão devem ser exercidas em conformidade com o interesse nacional, somente por brasileiros ou empresa constituída sob as leis brasileiras e que tenha sede e administração no país, na forma da lei.

Com relação ao petróleo, o artigo 177 atribuiu-lhe tratamento jurídico específico ante os demais recursos, não só no que se refere ao exercício das atividades de exploração e produção, mas também de refino, importação, exportação e transporte. No texto original da Constituição, tais atividades somente poderiam ser exercidas pela União, em regime de monopólio, sendo expressamente vedada, em conformidade com a regra contida no antigo parágrafo $1^{\circ}$ do artigo 177 , a concessão de qualquer tipo de participação, em dinheiro ou in natura, a qualquer ente público ou privado, ressalvados aqueles especificados na própria Constituição.

No entanto, com a Emenda Constitucional n. 9/95, o regime jurídico aplicável às atividades de exploração e produção de petróleo foi profundamente alterado, passando a União a poder contratar, nos termos da nova redação dada ao parágrafo $1^{\circ}$ do artigo 177 , empresas estatais ou privadas para a execução das atividades mencionadas, "observadas as condições estabelecidas em lei" (grifos nossos).

A lei a que se refere o dispositivo constitucional é justamente a Lei n. 9.478/97,25 cujo artigo 26, ao qual foi feita alusão, dentre outros, teve sua constitucionalidade questionada pelos seguintes argumentos:

Atualmente, outras normas regulam, ao lado da Lei n. 9.478/97, o artigo 177 da Constituição Federal, quais sejam: Lei n. 12.351/2010, que instituiu o contrato de partilha da produção, Lei n. 12.304/2010, que criou a PPSA para gerir os contratos de partilha e Lei n. 12.276/2010, que criou o contrato de cessão onerosa. 
1) A manutenção da expressão monopólio, no caput do artigo 177 , ao lado da possibilidade de contratação de empresas públicas e privadas para o exercício das atividades de exploração e produção de petróleo, deveria ser entendida no sentido de que se flexibilizou o monopólio da atividade, sem que, com isso, fosse alterado o monopólio da União sobre a propriedade do petróleo, que não poderia ser alienado.

2) O comando estatuído no artigo 176 da Constituição, segundo o qual o concessionário teria direito ao produto da lavra, representaria uma regra geral aplicável a todo e qualquer tipo de recurso natural, ao passo que o artigo 177 conteria disposiçôes especiais aplicáveis somente ao petróleo, o qual não poderia ser alienado ao concessionário após a sua extração, em virtude da manutenção do monopólio da União sobre a propriedade desse bem.

Atribuindo razão ao primeiro argumento, posicionou-se o Ministro Marco Aurélio pela inconstitucionalidade do artigo 26, de acordo com os seguintes motivos expostos em seu voto:

Ora, se o monopólio previsto na Carta da República se fizesse no sentido da Lei n. 9.478/97, de fato não haveria mais qualquer tipo de monopólio, e sim mera autorização administrativa, porque ao governo caberia tão somente fiscalizar a realizaçáo das atividades por particulares, de modo que tais condutas, desenvolvidas com o fim de atender ao interesse particular, não viessem a ofender o interesse público. Isso, obviamente, nada tem a ver com o conceito de monopólio! Seria interpretar a Constituição Federal a partir da lei, em uma clara inversão de valores hermenêuticos.

O conceito de monopólio, em sua origem, é de natureza econômica e significa dizer que alguém possui o controle exclusivo do comércio de certa mercadoria. Poder-se-ia afirmar, admito, que o termo não conduz, necessariamente, ao controle de toda a propriedade do bem, de modo que, mesmo quem detenha a atividade monopolizada, poderá dispor de parte dessa propriedade.

Bem diversa, entretanto, é a situação prevista na cabeça do artigo 26 da Lei n. 9.478/97, por meio da qual se pretende transferir totalmente a propriedade do petróleo aos concessionários. Esse regime não se coaduna com o monopólio estabelecido constitucionalmente, porque retira da Uniáo qualquer ingerência sobre a propriedade do bem, passando apenas a regular a atividade comercial exercida pelos particulares. Repita-se: monopólio não se confunde com autorização administrativa, porque a finalidade daquele é garantir a atuação de acordo com o interesse coletivo, preservando o interesse público, enquanto esta atende a objetivo eminentemente privado (grifos nossos).

Prossegue o Ministro:

em momento algum houve quebra do monopólio, mesmo porque a própria redação do artigo 177, cabeça, remete a tal fato, norteando o sentido jurídico-constitucional do parágrafo. O controle continua pertencendo à União. Apenas a partir da Emenda 
Constitucional n. 9, a execução das operaçôes deixou de ser exclusiva da Petrobras, de modo que atualmente pode ser efetuada por outras empresas, mediante contrato de prestação de serviço. Eis o sentido da expressão a Uniāo poderá contratar com empresas estatais ou privadas a realização das atividades previstas nos incisos I a IV deste artigo, observadas as condições estabelecidas em lei (grifos nossos).

A conclusão a que chega o Ministro Marco Aurélio é a de que a atribuição do produto da lavra ao concessionário tornaria sem sentido a expressão monopólio, contida no caput do artigo 177, pois como o Estado já teria aberto mão do monopólio da atividade em si, restava-lhe o exercício do monopólio sobre a propriedade do bem. A sua alienação ao particular no momento da sua extração - argumenta - retiraria da União qualquer ingerência sobre a propriedade do bem, passando esta apenas a regular a atividade comercial exercida pelos particulares. Diante de tais considerações, propugna que o único modelo contratual constitucionalmente autorizado a reger a exploração e produção de petróleo no território brasileiro seria o contrato de serviço.

$\mathrm{Na}$ doutrina, o mesmo entendimento é compartilhado por Clève e Martins, para quem "o monopólio de que trata o artigo 177 refere-se à propriedade, implicando exclusividade a titularidade de certo produto ou serviço, ou seja, propriedade de um só" (2004, p. 45). Desse modo, ao garantir a apropriação do recurso extraído pelo contratado, a Lei do Petróleo teria violado o referido comando constitucional.

Ao se referirem à Emenda Constitucional n. 9/95, os autores afirmam que esta não quebrou o monopólio no setor petrolífero, motivo pelo qual uma lei ordinária não poderia fazê-lo. Repisam que, ainda que por hipótese a Emenda Constitucional tivesse legitimamente modificado o regime de monopólio, "tal se daria tão somente quanto às atividades da Petrobras, e não quanto à titularidade da União (que engloba, necessariamente, a propriedade sobre o recurso mineral explorado)" (2004, p. 46).

Discordando dos argumentos apresentados, os quais conduziriam à conclusão de que seria inconstitucional a utilização de qualquer modelo contratual no Brasil que remunerasse o contratado por meio da transferência do produto da lavra, o Ministro Eros Grau, seguido pela maioria da Corte, atribuiu interpretação diversa ao conteúdo das normas jurídicas veiculadas por meio dos artigos 176 e 177 da Constituição, baseando-se nas razões a seguir resumidas:

1) Citando extensa doutrina jurídica e econômica, ensina que o termo monopólio refere-se tão somente à situação em que determinada atividade econômica é exercida por apenas um agente econômico, não havendo que se falar, portanto, em monopólio de propriedade.

2) Argumenta que se antes da Emenda Constitucional n. 9/95 a União tinha o dever de exercer diretamente as atividades de exploração e produção de petróleo sob o regime de monopólio, por haver norma constitucional (artigo 177, caput) 
que lhe impunha tal comportamento, após, o seu exercício (do monopólio) passou a ser uma escolha a cargo do legislador ordinário. Assim, tem-se que a manutenção da expressão monopólio no caput do artigo 177 - longe de ter perdido sua utilidade - justifica-se por este continuar sendo um caminho possível, a ser adotado pela União, para o exercício das atividades mencionadas anteriormente, não sendo mais, porém, o único.

Sem dúvidas, a definição precisa do termo monopólio mostrou-se fundamental para a compreensão da questão. Conforme sustentado por Grau em seu voto, tal conceito "não se presta a explicitar características da propriedade, de modo que não cabe aludirmos a monopólio de propriedade". Para tanto, pautou-se pela lição de Fábio Konder Comparato: "o monopólio, portanto, diz respeito a uma atividade empresarial, nada tendo a ver com o domínio e a propriedade". Citou ainda Pontes de Miranda, para quem:

monopolizar não é desapropriar, nem encampar. Desapropria-se ou encampa-se sem se monopolizar, como se, havendo duas ou mais empresas que exploram determinado ramo de indústria ou de comércio, a entidade estatal desapropria os bens da empresa, ou encampa a empresa, e não se dirige contra as outras. Pode a entidade estatal desapropriar os bens de todas as empresas existentes, sem estabelecer monopólio, isto é, sem proibir que se instalem e funcionem outras empresas com a mesma atividade.

Com base no exposto, partindo da premissa de que o texto constitucional alude a monopólio de atividade, e não de propriedade, conclui o Ministro Eros Grau que "a propriedade do resultado da lavra das jazidas de petróleo, de gás natural e de outros hidrocarbonetos fluidos pode ser atribuída a terceiros pela União, sem qualquer ofensa à reserva do monopólio, contemplada no artigo $177 \mathrm{da}$ Constituição", sendo constitucional, portanto, o artigo 26 da Lei n. 9.478/97.

A interpretação conferida pela Corte ao dispositivo constitucional, de fato, parece a mais acertada. Defender que o termo monopólio, previsto no caput do artigo 177, refere-se a monopólio da propriedade seria alargar em demasia o conteúdo da expressão, sedimentada não apenas na doutrina jurídica, mas também na econômica. $\mathrm{O}$ próprio Ministro Marco Aurélio reconhece o conceito de monopólio como referente a uma atividade econômica, conforme exposto em seu voto citado anteriormente.

Certamente, o fato de o monopólio sobre as atividades de exploração e produção de petróleo ter perdido o seu caráter impositivo, deixando de ser uma norma jurídica cujo modal deôntico consubstancia uma obrigação, para atribuir-lhe uma permissão, não esvazia o sentido da expressão aposta no caput do dispositivo, tanto que, a qualquer momento, a União pode retomar para si a exclusividade no exercício de tais atividades, mediante a edição de Lei Ordinária, respeitadas as obrigações assumidas no regime precedente. Esse é o posicionamento ao qual também se filia Alexandre de Moraes, para quem: 
Não se deve perder de vista que, mesmo a partir da EC n. 9/95, a União permaneceu com a titularidade do domínio sobre os recursos minerais, inclusive em relação ao petróleo e ao gás natural, conforme já analisado o art. 20, IX, da CF, porém, a nova redação do parágrafo primeiro do art. 177 passou a permitir à União uma opção, qual seja, a possibilidade de escolher entre a manutenção do sistema de pesquisa e lavra atual ou a adoção de um novo sistema, com a consequente contratação de empresas estatais ou privadas, nos termos da lei. (...) Trata-se, pois, de uma nova concepção de monopólio, não mais relacionado à intervenção estatal no domínio econômico com exclusividade no controle dos meios de produção (intervenção por absorção), mas sim relacionado ao monopólio de escolha do Poder Público, que poderá, conforme as normas constitucionais, optar entre a manutenção da pesquisa e a lavra das jazidas de petróleo e gás natural e outros hidrocarbonetos fluidos por uma só empresa, ou, ainda, pela contratação com empresas estatais ou privadas (2001, p. 163-166).

Da mesma forma, entende Alfredo Ruy Barbosa, para quem após a Emenda Constitucional n. 9/95 a União continuou como titular do monopólio federal, no entanto, passou a deter, paralelamente, "o direito de decidir, a seu critério exclusivo, quem deverá exercer as atividades indicadas no art. 177, caput, da Constituição. Isso porque - repita-se - a EC n. 9/95 extinguiu o monopólio sobre o exercício dessas atividades, mas não sobre as próprias atividades" (2005, p. 24). Em consequência, continua em sua exposição, "por motivos de interesse coletivo ou de segurança nacional, a União poderá manter sob o seu domínio e controle direto o exercício das atividades de exploração e lavra de petróleo e gás, concedendo o exercício exclusivo dessas atividades a uma empresa integrante da Administração Pública Federal" (2005, p. 24).

Diante de todas essas considerações, parece claro que a Constituição atribuiu uma opção ao legislador ordinário, afinal, independentemente de qual regime contratual for adotado, em algum momento, o governo alienará o petróleo a uma companhia pública ou privada. Ainda que se adote o contrato de serviço, defendido pelo Ministro Marco Aurélio como o único autorizado pela Constituição brasileira a reger as relaçôes entre Estado e empresas petrolíferas, após a entrega do recurso extraído ao ente público, este precisará firmar novo contrato, agora contrato de compra e venda, por meio do qual, finalmente, o petróleo será igualmente alienado, mediante o pagamento do preço pelo recurso em dinheiro, que se constituirá em receita pública. No mesmo sentido, ciente de que fatalmente, cedo ou tarde, o petróleo findará por ser alienado, qualquer que seja o modelo contratual adotado, afirma Eros Grau que:

essas contratações - contratações, note-se bem; não concessões - seriam materialmente impossíveis sem que os contratados da União se apropriassem, direta ou indiretamente, do produto da exploração das jazidas de petróleo, de gás natural e de outros hidrocarbonetos fluídos. 
A apropriação direta ou indireta - enfatizo - no quadro das inúmeras modalidades de contraprestação atribuíveis ao contratado, a opção por uma das quais efetivamente consubstancia, como anteriormente afirmado, uma escolha política.

Resta, pois, analisar o segundo argumento defendido em favor da inconstitucionalidade do artigo 26 da Lei do Petróleo. Para o Ministro Carlos Brito, o fato de o artigo 176 da Constituição Federal conter comandos gerais sobre todos os recursos minerais, assegurando ao concessionário a propriedade do produto da lavra, e, logo em seguida, lançar disposições especiais no artigo 177 sobre dois deles (petróleo e gás), estaria a impor um limite ao legislador ordinário, que não poderia deixar de observar a regra específica (a qual vedaria a transferência do produto da lavra), aplicando ao petróleo o mesmo regime conferido aos demais minérios. Para o Ministro, "o cânone hermenêutico a observar só pode ser este: aplica-se toda a parte geral dos dispositivos da Constituição, mas somente naquilo que não conflitar com a sua parte especial. Elementar regra de eliminação de antinomia normativa”.

Como dito anteriormente, a norma do artigo 177 não veda a transferência do produto da lavra ao contratado logo após a sua extração (característica que informa os contratos de concessão), concedendo um direito de escolha ao governo brasileiro de, a seu critério, alienar ou não o petróleo diretamente ao concessionário. Não fosse essa norma - especial em relação ao artigo 176 -, cairia o petróleo na regra geral instituída pelo artigo 176, de modo que também para este recurso qualquer contratação efetuada pelo Estado visando a sua extração, deveria ser feita pelo regime de concessão, o que não ocorre em nosso ordenamento.

Por fim, com vistas a afastar possíveis dúvidas que possam permanecer sobre o tema, analisam-se também as proposições formuladas por Bercovici, para quem haveria uma regra constitucional implícita segundo a qual, via de regra, todos os recursos minerais seriam inalienáveis, de modo que a regra contida no artigo 176 seria "uma exceção de alienabilidade ao regime jurídico dos bens minerais, por isso expressa constitucionalmente" (2011, p. 295), permanecendo o petróleo sujeito ao dito regime geral. Primeiramente, cabe destacar que não se vislumbra como extrair do texto constitucional um "princípio geral de inalienabilidade dos recursos naturais”. Na verdade, há uma regra geral aplicável a todos os recursos minerais prevista no artigo 176, como bem exposto pelo Ministro Carlos Brito, segundo a qual se confere ao concessionário o produto da lavra. $\mathrm{O}$ artigo 177 é que porta regra específica em relação a este, conforme explicado anteriormente. Contudo, ainda que se cogitasse da existência de tal princípio, o artigo 177, tal qual o artigo 176, teria excepcionado o petróleo desse regime, embora de maneira diversa do artigo 176, possibilitando também a sua alienação ao particular, conforme visto anteriormente. 
O autor defende ainda que:

Se, de fato, como entendeu a maioria do Supremo Tribunal Federal, a Emenda n. 9/95 e a Lei n. 9.478/97 tornaram aplicável à exploração do petróleo e do gás natural as mesmas regras gerais previstas no artigo 176, especialmente a atribuição da propriedade do produto da lavra ao concessionário, não resta mais nenhuma distinção entre uma concessão de exploração de minérios e uma concessão de exploração de petróleo. Se o produto da lavra é atribuído ao concessionário, qual é a diferença entre uma atividade econômica monopolizada pela União (a exploração de petróleo e gás natural) e uma atividade econômica não monopolizada pela União (a exploração de recursos minerais em geral? (2011, p. 295-296)

Em resposta ao questionamento proposto, afirma-se, mais uma vez: a diferença é que para todos os minérios não há liberdade de escolha para o ente público, estando este proibido de obstar o direito da empresa minerária de se apropriar do produto da lavra logo depois de extraído. A contratação se dará, necessariamente, por meio do contrato de concessão. Por outro lado, com relação ao petróleo, o ente público continuará livre para, por meio de lei, eleger momento diverso à transferência da propriedade do bem, seja no momento da extração (peculiar ao contrato de concessão), seja em momento posterior (característica dos contratos de partilha da produção e de serviço).

\subsection{DOS CONTRATOS DE EXPLORAÇÃO E PRODUÇÃO DE PETRÓLEO NO BRASIL}

Com base no exposto, serão abordadas as principais características que informam cada um dos contratos petrolíferos adotados no Brasil. O tema é bastante complexo, pois, conforme será visto, em um único instrumento contratual coexistem negócios jurídicos distintos, cada qual com natureza jurídica própria (por exemplo, acordo de empreitada e de compra e venda no mesmo contrato), cuja diferenciação se mostra essencial para que, nas seções que se seguem, seja possível compreender a natureza das prestaçóes devidas a cada uma das partes, notadamente das receitas auferidas pelo Estado brasileiro com a alienação do petróleo, o que tem sérias implicações na forma como tais recursos financeiros serão classificados nas Leis Orçamentárias e, consequentemente, utilizados por todos os entes federativos.

\subsubsection{Contrato de concessão}

O modelo brasileiro de contrato de concessão, regulado pela Lei n. 9.478/97, segue, de maneira geral, as regras adotadas internacionalmente neste tipo de contrato. Isto se infere da análise do artigo 26 da referida lei, segundo o qual a empresa concessionária é obrigada a "explorar, por sua conta e risco e, em caso de êxito, produzir petróleo ou gás natural em determinado bloco, conferindo-lhe a proprie- 
dade desses bens, depois de extraídos, com os encargos relativos ao pagamento dos tributos incidentes e das participaçôes legais ou contratuais correspondentes".

O seu objeto foi definido de maneira mais detalhada na cláusula segunda do modelo de Contrato de Concessão firmado entre a ANP e a contratada na décima rodada de licitação, realizada no ano de 2008, nos seguintes termos:

2.1 Este Contrato tem por objeto a execução, pelo Concessionário, das Operações especificadas no ANEXO II - Programa de Trabalho e Investimento, e qualquer outra atividade adicional de Exploração que o Concessionário possa decidir realizar dentro de cada Bloco integrante da Área da Concessão, visando a permitir que Petróleo e Gás Natural sejam produzidos em condiçôes comerciais na Área da Concessão, e no caso de qualquer Descoberta, a Avaliaçãa, o Desenvolvimento e a Produção dos Hidrocarbonetos pertinentes, tudo nos termos aqui definidos.

Veja-se que no modelo brasileiro, como no restante do mundo: (i) a propriedade de todo o petróleo extraído é transferida ao contratado no momento em que passa pela boca do poço; e (ii) o Estado opta por receber o resultado contratado integralmente em pecúnia, por meio dos royalties e participações especiais, conforme está previsto no artigo 45 da Lei do Petróleo.

Tanto os royalties como as participações especiais são obrigações de resultado, apurados em uma porcentagem sobre a produção de petróleo e gás natural em cada campo.

O Decreto n. 2.705/98, que regulamentou a Lei n. 9.478/97 (Lei do Petróleo), definiu-os da seguinte maneira: "art. 11. Os royalties previstos no inciso II do artigo 45 da Lei n. 9.478, de 1997, constituem compensação financeira devida pelos concessionários de exploração e produção de petróleo ou gás natural, e serão pagos mensalmente, com relação a cada campo, a partir do mês em que ocorrer a respectiva data de início da produção, vedada quaisquer deduções”. Por sua vez, de acordo com o artigo 21, "a participação especial prevista no inciso III do art. 45 da Lei n. 9.478, de 1997, constitui compensação financeira extraordinária devida pelos concessionários de exploração e produção de petróleo ou gás natural, nos casos de grande volume de produção ou de grande rentabilidade, conforme os critérios definidos neste Decreto, e será paga, com relação a cada campo de uma dada área de concessão, a partir do trimestre em que ocorrer a data de início da respectiva produção".

Uma análise mais detalhada de ambos, sobretudo com relação a sua natureza jurídica, será feita no capítulo seguinte.

No que tange ao momento exato em que a propriedade do bem é transferida, consta na cláusula 11.2 do mesmo modelo citado anteriormente, que "o concessionário 
receberá e assumirá, no Ponto de Medição da Produção, a propriedade dos volumes de Petróleo e Gás Natural", o qual deve vir especificado em cada contrato firmado.

Por fim, encontram-se no artigo 43 da Lei do Petróleo as cláusulas essenciais do contrato, as quais deverão refletir fielmente as condições do edital e da proposta vencedora. São elas: I - a definição do bloco objeto da concessão; II - o prazo de duração da fase de exploração e as condições para sua prorrogação; III - o programa de trabalho e o volume do investimento previsto; IV - as obrigações do concessionário quanto às participações, conforme o disposto na Seção VI; V - a indicação das garantias a serem prestadas pelo concessionário quanto ao cumprimento do contrato, inclusive quanto à realização dos investimentos ajustados para cada fase; (VI) a especificação das regras sobre devolução e desocupação de áreas, inclusive retirada de equipamentos e instalaçôes, e reversão de bens; VII - os procedimentos para acompanhamento e fiscalização das atividades de exploração, desenvolvimento e produção, e para auditoria do contrato; VIII - a obrigatoriedade de o concessionário fornecer à ANP relatórios, dados e informações relativos às atividades desenvolvidas; IX - os procedimentos relacionados com a transferência do contrato, conforme o disposto no art. 29; X - as regras sobre solução de controvérsias relacionadas com o contrato e sua execução, inclusive a conciliação e a arbitragem internacional; XI - os casos de rescisão e extinção do contrato; XII - as penalidades aplicáveis na hipótese de descumprimento pelo concessionário das obrigações contratuais.

Comentados os seus principais aspectos, passa-se a discorrer acerca da natureza jurídica dessa espécie contratual.

Conforme analisado no item 3.2, grande parte da doutrina posiciona-se no sentido de que o objeto dos contratos de concessão petrolífera seria o usufruto de um bem público. O Estado proprietário dos recursos permitiria que o concessionário utilizasse a jazida, dela retirando os frutos (o petróleo), sendo remunerado por isso na forma de royalties.

No mesmo item 3.2 explicou-se que, em sua gênese, de fato era possível adotar o entendimento segundo o qual o objeto dos contratos de concessão petrolífera era o usufruto de um bem público, tendo em vista que até $1921^{26}$ o petróleo e o solo/ subsolo eram considerados uma única realidade. Não se concebia o petróleo como componente de uma jazida finita, cuja extração de cada barril leva a sua gradual

\footnotetext{
26 A partir da Lei n. 4.265, de 15 de janeiro de 1921, as jazidas de recursos minerais (compreendidas aí também as jazidas de petróleo) passaram a ser tratadas no direito brasileiro como propriedade distinta do solo/subsolo.
} 
exaustão, como ocorre hodiernamente. De acordo com o ordenamento jurídico da época, o petróleo era considerado parte integrante do solo, de modo que a sua extração não era capaz de exaurir permanentemente o bem-mãe que era o solo. Em virtude disso, ainda que com alguma discussão, seria possível se falar em usufruto do petróleo nesse cenário.

Contudo, nos dias atuais é um contrassenso afirmar que o Estado possa firmar com outrem um contrato para o uso de um bem público finito, não renovável, quando referido uso provoque o exaurimento do próprio bem. É condição sine qua non para a caracterização de um contrato de simples uso ou um contrato de exploração de bem público (exploração no sentido de usufruto ou uso como poderes de disponibilidade da coisa) que após o período de vigência do acordo - não importa se um, cinco, ou vinte anos - o bem ainda esteja disponível na natureza, passível de ser utilizado e gerar renda continuamente. Se a apropriação do recurso pelo contratado promover o seu exaurimento, há claramente uma alienação, e não um uso ou usufruto.

Sendo assim, o contrato de concessão petrolífera é, na verdade, um instrumento por meio do qual o Estado vende para a empresa contratada o petróleo de sua propriedade, recebendo em contraprestação um preço chamado de royalty. Mas não só. No referido contrato há concomitantemente dois negócios jurídicos a serem observados: a) um de compra e venda do petróleo que caberia à União, cujo pagamento recebido pelo ente público é chamado de royalty; e outro, b) de empreitada, correspondente à contratação da empresa para a execução das atividades de exploração e produção de petróleo, a qual finda por ser remunerada não em pecúnia, como ocorre nos contratos de serviço, mas em óleo.

No contrato de concessão, embora o Estado também pretenda obter o mesmo resultado, este é mais difícil de ser visualizado na prática do que nos contratos de partilha ou de serviço; isto porque, no de concessão, a despeito da finalidade pretendida ainda ser a extração do petróleo, opta o ente público por vendê-lo diretamente à mesma empresa que extraiu o recurso, recebendo sua participação no resultado, portanto, convertida em pecúnia, na forma de royalties, conforme será analisado detalhadamente nos capítulos seguintes.

Há no contrato de concessão, portanto, um acordo concomitante de compra e venda, de modo que a parcela em petróleo que caberia ao Estado é alienada diretamente à empresa concessionária, que paga, em contraprestação, um valor em dinheiro chamado de royalty, correspondente ao preço pelo bem público adquirido. 


\subsubsection{Contrato de partilha}

A partir da publicação da Lei n. 12.351, de 22 de dezembro de $2010,{ }^{27}$ a contratação de empresa ou consórcio de empresas para o exercício das atividades de exploração e produção de petróleo no Brasil, nas áreas do pré-sal ou naquelas consideradas estratégicas, deverá se dar por meio de contrato de partilha da produção, a ser firmado com a União, representada pelo Ministério de Minas e Energia, e gerido pela Pré-Sal Petróleo S.A. (PPSA), empresa pública instituída pela Lei n. $12.304 / 2010$ para tal finalidade.

Segundo a Lei n. 12.351/2010, a contratação de empresa para o desempenho das atividades de exploração e produção de petróleo pode ser feita de maneira direta com a Petrobras, dispensada a licitação ou mediante processo licitatório, na modalidade leilão (art. $8^{\circ}$, I e II), do qual poderão participar empresas privadas interessadas

A introdução do modelo de partilha da produção no Brasil foi justificada na Exposição de Motivos n. 38 do Projeto de Lei n. 5.938/2009, nos seguintes termos: "O anúncio da descoberta de grandes quantidades de petróleo e gás em nova província petrolífera, denominada Pré-Sal, na Bacia de Santos, no ano de 2007, levou o Conselho Nacional de Política Energética - CNPE a emitir a Resolução n 6, de 8 novembro de 2007, que, então, determinou a exclusão da $9^{a}$ Rodada de Licitações da Agência Nacional do Petróleo, Gás Natural e Biocombustíveis - ANP de quarenta e um blocos situados nas Bacias do Espírito Santo, de Campos e de Santos. 3. Tal exclusão decorreu do fato de os blocos estarem dentro da nova província, apresentando grande potencial para novas descobertas, o que levou o Governo a avaliar a necessidade de mudanças, no atual marco legal, destinadas a contemplar este novo paradigma na exploração e produção de petróleo e gás natural, de modo a aumentar o controle e a participação da União nos futuros empreendimentos e, ao mesmo tempo, respeitar os contratos de concessão vigentes. 4. Portanto, considerando o novo contexto, mostrou-se evidente que o atual marco regulatório firmado pela Lei n. 9.478, de 6 de agosto de 1997 - Lei do Petróleo - não é suficiente para permitir, em vários sentidos, o adequado aproveitamento das reservas descobertas na nova província petrolífera do Pré-Sal. O marco regulatório vigente, que dispõe sobre a política energética nacional, as atividades relativas ao monopólio do petróleo e institui o Conselho Nacional de Política Energética e a Agência Nacional do Petróleo, foi fundamentado nas premissas que levaram à promulgação da Emenda Constitucional n. 9/ 95. Assim, disciplinou-se a possibilidade de a União contratar as atividades de pesquisa e lavra das jazidas de petróleo e gás natural e outros hidrocarbonetos fluidos, existentes no território nacional, por meio de concessão, a serem desenvolvidas por empresas constituídas sob as leis brasileiras e com sede e administração no País.

5. O referido marco legal foi concebido de modo a contemplar as condiçôes vigentes àquela época, quando o País tinha produção relativamente pequena, o barril de petróleo era cotado em torno de dezenove dólares e o risco exploratório era considerado elevado. (...)

Testes indicaram a existência de grandes volumes de óleo leve de alto valor comercial (30 graus API), com grande quantidade de gás natural associado. Trata-se de áreas nas quais são estimados riscos exploratórios extremamente baixos e grandes rentabilidades, o que determina a necessidade de marco regulatório coerente com a preservação do interesse nacional, mediante maior participação nos resultados e maior controle da riqueza potencial pela União e em benefício da sociedade". 
em formar consórcio com a companhia estatal. Em todo caso, em conformidade com o que dispõe o artigo $4^{\circ}$, a Petrobras será a operadora de todos os blocos contratados sob o regime de partilha de produção, sendo-lhe assegurada, a este título, participação mínima no consórcio de $30 \%$. Caso deseje ampliar a sua participação no consórcio, a Petrobras deverá igualmente participar do processo licitatório (art. 14).

No modelo brasileiro - e com base no exposto no tópico anterior, acerca da natureza dos contratos de E\&P - a empresa petrolífera é contratada pelo Estado que visa à extração do petróleo armazenado no subsolo, para o que a contratada deverá desempenhar uma série de atividades coordenadas de modo a cumprir o resultado esperado, entregando a parcela do óleo que cabe ao ente público, remunerando-se com o restante da produção.

Diferentemente do que ocorre no contrato de concessão, a empresa não adquire a propriedade do óleo extraído de maneira automática após a sua passagem pela boca do poço, mas em momento posterior a ser definido no contrato, chamado de ponto de partilha (art. 2º, XI, Lei n. 12.351/2010).

A remuneração devida à companhia petrolífera pelo trabalho prestado é feita pelo que a lei chamou de "custo em óleo" e pela "parcela do excedente em óleo". O custo em óleo, de acordo com o inciso II, art. 2o da Lei n. 12.351/2010, é a "parcela da produção de petróleo, de gás natural e de outros hidrocarbonetos fluidos, exigível unicamente em caso de descoberta comercial, correspondente aos custos e aos investimentos realizados pelo contratado na execução das atividades de exploração, avaliação, desenvolvimento, produção e desativação das instalações".

O excedente em óleo, por sua vez, corresponde à parcela da produção de petróleo a ser repartida entre a União e o contratado, segundo critérios definidos no contrato, resultante da diferença entre o volume total da produção e as parcelas relativas ao custo em óleo, aos royalties devidos e, quando o bloco se localizar em terra, à participação dos seus proprietários, equivalente a até $1 \%$ do valor da produção (art. 2o, III; e art. 43 da Lei n. 12.351/2010).

Após o recebimento da parcela do óleo devida por cada uma das partes, deverão elas agora realizar contrato de compra e venda desse recurso, estando a União sujeita às regras impostas pelo artigo 45 da Lei do Contrato de Partilha, analisadas a seguir.

Contudo, a forma como o governo brasileiro optou por perceber o resultado contratado da companhia petrolífera, no modelo de partilha da produção, difere do que comumente se pratica na experiência internacional, pois, enquanto em sua forma mais usual o Estado recebe o resultado pretendido integralmente em óleo, para, em seguida, comercializá-lo, por exemplo, com refinarias, por meio de outro instrumen- 
to contratual, no modelo brasileiro há um sistema misto. Opta o Estado por receber parte em óleo - a parcela do excedente em óleo anteriormente referida - e parte convertida em pecúnia, por meio de negócio jurídico de compra e venda inserto no próprio contrato de partilha, pelo que a empresa contratada pagará um preço à União, chamado de royalty, adquirindo a propriedade do petróleo correspondente.

O valor dos royalties aplicável aos contratos de partilha foi definido em 15\%, incidente sobre a produção total, a ser pago à União, que deverá efetuar o repasse de parte desses recursos a Estados e Municípios, permanecendo o restante na Conta Única do Tesouro, para ser transferido aos órgãos da administração federal direta, conforme os limites estipulados na Lei Orçamentária da União.

As cláusulas essenciais a serem observadas no contrato foram elencadas no artigo 29 da Lei n. 12.351/2010, dentre as quais constam: I - a definição do bloco objeto do contrato; II - a obrigação de o contratado assumir os riscos das atividades de exploração, avaliação, desenvolvimento e produção; III - o direito do contratado à apropriação do custo em óleo, exigível unicamente em caso de descoberta comercial; IV - os limites, prazos, critérios e condiçōes para o cálculo e apropriação pelo contratado do custo em óleo e do volume da produção correspondente aos royalties devidos; $\mathrm{V}$ - os critérios para cálculo do valor do petróleo ou do gás natural, em função dos preços de mercado, da especificação do produto e da localização do campo; VI - as regras e os prazos para a repartição do excedente em óleo, podendo incluir critérios relacionados à eficiência econômica, à rentabilidade, ao volume de produção e à variação do preço do petróleo e do gás natural, observado o percentual estabelecido segundo o disposto no art. 18; VII - o prazo de duração da fase de exploração e as condições para sua prorrogação; VIII - o programa exploratório mínimo e as condições para sua revisão (XII); os critérios para formulação e revisão dos planos de exploração e de desenvolvimento da produção, bem como dos respectivos planos de trabalho, incluindo os pontos de medição e de partilha de petróleo, de gás natural e de outros hidrocarbonetos fluidos produzidos; XIII - os critérios para devolução e desocupação de áreas pelo contratado, inclusive para a retirada de equipamentos e instalações e para a reversão de bens; XIV - as regras sobre solução de controvérsias, que poderão prever conciliação e arbitragem; XV - o prazo de vigência do contrato, limitado a 35 (trinta e cinco) anos, e as condições para a sua extinção; XVI - o valor e a forma de pagamento do bônus de assinatura.

\subsubsection{Contrato de cessão onerosa}

O terceiro e último instrumento contratual utilizado pelo Estado brasileiro visando a explotação do petróleo presente no seu subsolo é o contrato de cessão onerosa. 
$\mathrm{Na}$ verdade, essa é uma forma peculiar de contrato petrolífero, como explica Viegas:

A cessão de direitos à Petrobras não se enquadra nem no regime de concessão, nem no de partilha de produção. Por um lado, não se enquadra no regime atualmente vigente de concessão, pois não há previsão de processo de licitação e não prevê cobrança de bônus de assinatura e de participação especial. Por outro lado, a cessão não é enquadrada no regime de partilha da produção, pois o óleo extraído será da Petrobras, e não compartilhado com a União (2010, p. 7).

Dada a sua singularidade, inclusive com relação ao que é praticado internacionalmente, será feita uma análise mais detalhada do tema, explicitando, além dos contornos jurídicos desse "novo contrato", as razões que levaram à sua criação e as obrigações impostas a cada uma das partes.

É sabido que a descoberta do pré-sal provocou uma reformulação das estruturas jurídicas que até então regiam as atividades de exploração e produção de petróleo no Brasil. Elevou-se profundamente a participação da Petrobras no desenvolvimento dessas atividades, o que, ao tempo que a fortaleceu como empresa, lhe impôs grandes desafios, ${ }^{28}$ que exigem o investimento de cifras extremamente altas.

Visando capitalizar a Petrobras, dotando-a dos recursos necessários para levar a cabo a produção de petróleo na região do pré-sal, decidiu-se por realizar oferta pública de ações da empresa, ${ }^{29}$ aprovada pelo seu Conselho de Administração em $1^{\text {o }}$ de setembro de 2010. Segundo Francisco José Rocha de Sousa, esta operação compreendeu a emissão de "2.369 milhões de ações ordinárias e 1.901 milhão de açōes preferenciais, as quais foram vendidas aos preços de $\mathrm{R} \$ 29,65$ por ação ordinária e R\$26,30 por ação preferencial”, resultando, em 1 o de outubro de 2010, no aumento do seu capital na ordem de R\$120,25 bilhões (SOUSA, 2011, p. 12).

28 Sobre os desafios tecnológicos que envolvem a exploração e produção de petróleo na área do pré-sal, ver texto elaborado pela Petrobras, Disponível em: <http://www.petrobras.com.br/ minisite/presal/pt/uma-nova-fronteira/>. Acesso em: 8 maio 2012.

29 Conforme informação divulgada pela Petrobras, "foi protocolado na CVM, em 3 de setembro de 2010, o pedido de registro de oferta pública de distribuição primária de 2.174.073.900 novas ações ordinárias ("Açôes Ordinárias") e de 1.585.867.998 novas ações preferenciais ("Ações Preferenciais" e, conjuntamente com as Ações Ordinárias, "Ações”) de emissão da Companhia, todas nominativas, escriturais, sem valor nominal, livres e desembaraçadas de quaisquer ônus ou gravames, incluindo sob a forma de American Depositary Shares ("ADS"), representados por American Depositary Receipts (“ADR”), todos livres e desembaraçados de quaisquer ônus ou gravames, a ser realizada simultaneamente no Brasil e no exterior ("Oferta Global” ou “Oferta”)” (PETROBRAS, 2010). 
Ao comentar a estratégia utilizada, Paulo Roberto Alonso Viegas afirma que: a operação de capitalização leva a Petrobras a emitir novas ações, cuja negociação resulta no aumento de seu Ativo e de seu Patrimônio Líquido, conferindo-lhe robustez e capacidade financeira para explorar o petróleo do pré-sal. Destaca-se que esse aumento de tamanho permitirá à estatal um maior endividamento, que lhe permita explorar, num primeiro momento, as reservas relativas à própria cessão onerosa de direitos de exploração. Tal exploração, por sua vez, deverá ser importante geradora de caixa futuramente (provavelmente a partir de 2016), contribuindo para a ampliação da capacidade das empresas de se financiar, visando à continuidade da exploração do pré-sal (2010, p. 6).

A ampliação do capital da Petrobras, por meio de oferta global de ações, além de ter por objetivo aumentar sua disponibilidade financeira, propiciou o aumento da participação da União no seu capital social, que passou de 39,8 para 48,3\% (SOUSA, 2011, p. 13).

Tendo em vista que a integralização das suas ações, bem como a aquisição de outras como forma de aumentar a sua participação no capital social da empresa, exigia um aporte financeiro substancial por parte da União, e que este ente não dispunha de recursos financeiros livres no seu orçamento no montante necessário para tal finalidade, o governo brasileiro decidiu utilizar como moeda de troca as reservas de petróleo contidas no subsolo. Estas, constituindo-se em ativos, são passíveis de valoração econômica negociável, o que, inclusive, é feito de maneira frequente por empresas petrolíferas. Contudo, como bem exposto por Francisco José Rocha de Sousa, porquanto a Lei n. 6.404, de 15 de dezembro de 1976 (a Lei das Sociedades Anônimas) não permite a revisão do valor de bens utilizados com esse propósito, "a União não poderia utilizar, de forma direta, os direitos de explorar e produzir petróleo e gás natural em área do Pré-sal para integralizar sua participação na oferta pública de ações da Petrobras" (2011, p. 14). Por esse motivo, em lugar de transferir diretamente seus ativos para a Petrobras em troca do aumento no seu capital, precisou firmar simultaneamente com a estatal uma outra operação, chamada de cessão onerosa, regida pela Lei n. 12.276/2010.

Obedecendo ao disposto nesta norma, em 3 de setembro de 2010 a União firmou com a Petrobras contrato por meio do qual cedeu à estatal 5 bilhôes de barris equivalentes de óleo, relacionando as seis áreas definitivas onde deverá ocorrer a extração (Florim, Franco, Sul de Guará, Entorno de Iara, Sul de Tupi, Nordeste de Tupi), além de uma contingente (Peroba), em troca do pagamento de $\mathrm{R} \$ 74.808$ bilhões, ${ }^{30}$ equivalentes na ocasião a US $\$ 42.533$ bilhões (pagos na assinatura do contrato).

30 "A Petrobras promoveu o pagamento do valor inicial do contrato de cessão onerosa com recursos obtidos na venda de ações ordinárias e preferenciais de sua emissão da seguinte forma: i) 
Do montante total recebido pela União, $\mathrm{R} \$ 42,9$ bilhões foram utilizados para financiar o aumento/integralização de sua participação no capital da Petrobras, "tendo a parcela restante ( $\mathrm{R}$ 21,9 bilhôes) servido para reforçar o superávit primário do governo central” (SOUSA, 2011, p. 10).

Ao analisar a legislação que regulou a cessão onerosa, bem como o próprio instrumento contratual firmado entre as partes, pensa-se haver imprecisões graves sobre o que de fato foi objeto de negócio jurídico entre a União e a Petrobras. Como afirmado anteriormente, a estatal brasileira pagou à União o montante de 74.808 bilhóes de reais, devidos, de acordo com a cláusula segunda do contrato de cessão onerosa, em contraprestação à aquisição de um direito de "exercício das atividades de pesquisa e lavra de petróleo, de gás natural e de outros hidrocarbonetos fluidos localizados na área do Pré-Sal”. Referida cláusula contratual guarda consonância com o disposto no artigo $1^{\circ}$ da Lei n. 12.276/2010, no qual se buscou definir o objeto do contrato da cessão onerosa:

Art. $1^{\circ}$ Fica a Uniāo autorizada a ceder onerosamente à Petróleo Brasileiro S.A. - PETROBRAS, dispensada a licitação, o exercício das atividades de pesquisa e lavra de petróleo, de gás natural e de outros hidrocarbonetos fluidos de que trata o inciso I do art. 177 da Constituição Federal, em áreas não concedidas localizadas no pré-sal (grifos nossos).

Na cláusula segunda do contrato em questão, tal objeto foi detalhado nos seguintes termos:

\section{CLÁUSULA SEGUNDA: OBJETO}

2.1. Este contrato tem por objeto a cessão onerosa, à Cessionária, do exercício das atividades de Pesquisa e Lavra de Petróleo, de Gás Natural e de outros Hidrocarbonetos Fluidos localizados na Área do Pré-Sal.

2.2. O exercício das atividades referido no parágrafo 2.1 é limitado à produção de 5 (cinco) bilhōes de Barris Equivalentes de Petróleo ("Volume Máximo"), nos termos do $\$ 2^{\circ}$ do art. 1o da Lei n. 12.276, de 2010 .

2.3. Como contraprestação pela Cessão Onerosa prevista no parágrafo 2.1, a Cessionária se obriga a efetuar o pagamento do Valor do Contrato à Cedente, na forma e prazo estabelecidos pela Cláusula Quarta deste Contrato (grifos nossos).

A doutrina sobre o tema tem se posicionado também de maneira unânime no sentido de que o objeto do contrato refere-se à transferência de um direito de exer-

R \$ 67,8 bilhões em Letras Financeiras do Tesouro - LFTs de que a União se valeu para integralizar sua participação no aumento do capital na empresa (Oferta Global); e R \$ 7 bilhões do seu caixa. Após o encerramento da referida operação, a Petrobras entregou à União os mencionados títulos" (SOUSA, 2011, p. 9). 
cício das atividades de E\&P (SOUSA, 2011) e (VIEGAS, 2010). Contudo, a compreensão exata do objeto transacionado por meio do contrato de cessão onerosa é mais complexa do que a análise dos referidos excertos, separada do restante dos termos do contrato, leva a crer em um primeiro momento.

Não faz sentido algum que uma empresa petrolífera pague pelo simples exercício de um direito de exploração e produção. A mera prática dessas atividades, por si só, não the atribui qualquer vantagem. O que levaria uma companhia a pagar por um direito de explorar e produzir petróleo, levar a cabo tais atividades, e posteriormente entregar o resultado da produção ao Estado? Onde estaria a comutatividade deste contrato? Seria o mesmo que afirmar que uma empresa deve pagar pelo direito de construir um prédio encomendado por um ente público, ou por ter o direito de lhe fornecer um bem ou um serviço, enfim, pagar pelo direito de contratar com a Administração Pública. ${ }^{31}$ Ora, sociedades civis têm interesse de contratar com o Estado, assim como com outros entes privados, pois visam realizar negócios com estes. A atribuição de um direito de explorar e produzir petróleo é apenas meio pelo qual a União instrumentaliza o contratado para atingir o resultado visado, que é a extração do petróleo, assim como faz quando atribui a uma construtora o direito de construir, sobre um terreno seu, um prédio público que tenha contratado.

Como exposto anteriormente, quando a ANP deseja obter dados sobre a potencial existência de petróleo em uma determinada região, ela contrata empresa para tal finalidade, remunerando-a pelo serviço prestado. Caso um Estado que adota o modelo de contract services acorde com empresa petrolífera a extração do petróleo de sua propriedade, pagar-lhe-á um preço pelo resultado proporcionado. No contrato de partilha da produção e no contrato de concessão, a empresa é remunerada com o óleo in natura, havendo em ambos, concomitantemente, negócio jurídico de compra e venda de petróleo inserto no contrato. No entanto, embora firmem o acordo de compra e venda no ato de assinatura do contrato, o qual desde então é tido como perfeito e acabado ${ }^{32}$ - repise-se, negócio jurídico distinto da

31 Eventual pagamento exigido, pelo mero direito de contratar com a Administração Pública, seria um encargo contratual relacionado ao procedimento de licitação para a escolha do contratante, a exemplo do que ocorre com o bônus de assinatura, presente nos contratos petrolíferos, o qual, entretanto, não tem qualquer relação direta com o objeto do contrato, como ocorre no caso dos royalties.

32 Para uma melhor compreensão disso, veja-se o que ensina Pontes de Miranda sobre o negócio jurídico de compra e venda: "A conclusão do contrato resulta do acôrdo do consenso. Concluso o contrato de compra-e-venda, há a vinculação, que é o efeito mínimo, e a irradiação posterior de efeitos. (...) Basta a assinatura do comerciante abaixo das cláusulas, ou com 
empreitada contratada -, tanto a obrigação de pagar, a cargo da empresa, como a de transferir a propriedade, devida pelo Estado, são pactuadas nestes contratos para que sejam efetuadas em momento diverso. $\mathrm{Na}$ concessão, a transferência da propriedade, efeito real do negócio jurídico de compra e venda, se dá no momento em que o petróleo passa pela boca do poço, ao passo que o correspectivo preço - os royalties lato sensu - deve ser pago posteriormente, no momento assinalado no contrato. No contrato de partilha da produção, a transferência da propriedade, como dito, se dá no ponto de partilha, especificado no contrato, assim como o do pagamento dos royalties.

Com base em tais premissas é que se pode afirmar que o montante pago pela Petrobras à União no dito contrato de cessão onerosa, após uma análise sistemática deste instrumento negocial, não corresponde simplesmente a um direito de exercício das atividades de exploração e produção. Constitui-se no preço devido pela Petrobras em contraprestação à venda do petróleo pela União. Contudo, neste contrato petrolífero, o momento do pagamento do preço foi acertado para ser efetuado em parte no ato de assinatura do contrato, e o restante posteriormente, por ocasião do pagamento dos royalties, diferindo, portanto, do que se pratica no contrato de concessão e de partilha da produção (em que o pagamento do preço é efetuado integralmente após a extração). De todo modo, nos três casos (contrato de concessão, de partilha da produção e de cessão onerosa) ocorre um negócio jurídico de compra e venda de bem futuro. Sobre o tema, lança-se mão, mais uma vez, das elucidativas lições de Pontes de Miranda:

Se o bem ainda não existe, não é isso obstáculo a que seja comprado e vendido. $\mathrm{O}$ contrato de compra-e-venda é consensual, por ele, promete-se. Tanto se pode prometer o que já existe como se pode prometer o que ainda não existe. Nada obsta, sequer, a que se acorde em que a propriedade e a posse se transferirão imediatamente após a existência do bem vendido. Não há a transferência da posse e da propriedade do que ainda não é in rerum natura. Porém nada obsta a que se prometa tal transferência e se acorde, desde logo, em que momento a propriedade e a posse serão transferidas. Prenhe a égua, nada impede que se venda e desde já se transfiram a propriedade futura e a

a expressão 'de acôrdo', ou outra semelhante, para se ter como concluído o contrato. (...)” A simultaneidade, no que se refere à compra-e-venda e à tradição, com a transmissão da propriedade, de modo nenhum traduz a correspondência entre a compra-e-venda e a sua consequência prestacional. Na compra-e-venda, com entrega imediata, ou simultânea, o que há é a simultaneidade de dois negócios jurídicos, o da compra-e-venda e o da transferência (acôrdo ou acôrdos de transmissão). Nunca, por si só, o contrato de compra-e-venda transfere, simultânea ou imediatamente, a propriedade e a posse. Para que isso se dê é preciso que tenha havido o acôrdo ou os acôrdos de transmissão, explícitos ou implícitos" (1972, t. XXXIX, p. 13, grifos nossos). 
futura posse do poldro que pode nascer (e é provável que nasça) - Nos casos em que o bem vendido está inserto em outro, como os frutos, estabelece a existência do bem determinado e a propriedade e a posse se transferem conforme o acordo de transmissão. A existência do bem e a sua existência autônoma são dois conceitos diferentes: o fruto, inclusive o animal concebido e não nascido, existe, porém ainda não existe autonomamente. De qualquer modo, a compra-e-venda de bem futuro, como a de bem futuramente autônomo, já se perfaz com as declarações bilaterais de vontade; e nada obsta a que o próprio acordo de transmissão da propriedade e da posse se conclua para a eficácia no momento adequado, ou mesmo escolhido. (...) A emptio spei vale e é eficaz. Uma vez que mais se prestou relevância à esperança do que à coisa (em vez da emptio rei speratae, tem-se a emptio spei), o comprador tem de pagar o preço mesmo se o bem não vem a existir, ou se nasce sem vida. O comprador levou em conta, para o preço, a probabilidade de êxito (1972, t. XXXIX, p. 19, grifos nossos).

A compreensão disso se torna cristalina quando se observam as demais cláusulas contidas no contrato. A princípio, bastaria a análise do seu anexo II para extirpar qualquer dúvida acerca do seu objeto, pois nele se encontram discriminados em uma tabela o volume de petróleo a ser extraído de cada um dos blocos cedidos, o valor do barril de petróleo extraído do respectivo bloco, e o valor total pago na cessão por cada bloco. Tome-se a título exemplificativo o bloco de Florim. Neste, autorizou-se a extração de um volume de 467 milhões de barris de óleo equivalentes, cujo barril foi avaliado em U\$ 9.0094, sendo devido por este campo o pagamento do montante de U\$ 4.207.389.800,00. Ao final da tabela, tem-se o valor total pago pela Petrobras no contrato de cessão onerosa, como resultado da soma pelo pagamento de cada barril de petróleo enterrado, em cada uma das áreas mencionadas no contrato.

Além disso, a cláusula trigésima segunda, que versa sobre a extinção do contrato pelo cumprimento do objeto, dispõe que:

\section{Extinção pelo Cumprimento do Objeto}

32.1 Extingue-se, de pleno direito, a cessão do exercício de pesquisa e lavra de Petróleo, Gás Natural e outros Hidrocarbonetos Fluidos, na Área do Contrato, com a Produção do volume de Barris Equivalentes de Petróleo previsto no parágrafo $2.2 \mathrm{e}$ Anexo II - Volumes e Valores da Cessão Onerosa.

Onde está escrito "extingue-se, de pleno direito, (...) com a produção do volume de barris equivalentes", leia-se: com a produção e consequente transferência da propriedade, que se dará no momento em que o petróleo passa pela boca do poço, em conformidade com o parágrafo $1^{\circ}$, artigo $1^{\circ}$ da Lei n. $12.276 / 2010$, mediante o pagamento do restante do preço à União, a título de royalties, correspondente ao resultado da extração, convertido em pecúnia, que cabe ao ente público. 
Diante de tais considerações, constata-se a inadequação da expressão "cessão onerosa” para designar o negócio jurídico firmado entre a União e a Petrobras, uma vez que ao fim e ao cabo, o que de fato ocorreu foi um negócio jurídico de compra e venda de petróleo.

De todo modo, a falta de técnica no nome atribuído ao contrato não traz consequências práticas importantes ao mundo do direito, desde que se reconheça a sua natureza, como bem expôs Pontes de Miranda sobre o tema:

COMPRA-E-VENDA E CESSÃO. Conforme temos dito, os regimes jurídicos da compra-e-venda stricto sensu, da compra-e-venda lato sensu e da compra-e-venda latissimo sensu tinham de ser diferentes. A cessão de créditos, a cessão de direitos que não são creditórios, nem de domínio, nem de posse, e a compra-e-venda de bens corpóreos ou incorpóreos suscetíveis de domínio e de posse, não cabem no mesmo quadro jurídico rígido. (...) na prática, a troca dos nomes (compra-e-venda, cessão) é sem relevância. $O$ intérprete tem de examinar o caso para saber de que espécie de negócio jurídico oneroso se trata (1972, t. XXXIX, p. 151, grifos nossos). 